\title{
WISCONSINAN MOLLUSCAN FAUNAS OF THE ILLINOIS VALLEY REGION
}

A. Byron Leonard John C. Frye

11. IPIPIS EEOLOGICA

SIJPHEY I IBRARY 1936

DIVISION OF THE

ILLINOIS STATE GEOLOGICAL SURVEY JOHN C.FRYE, Chief URBANA 

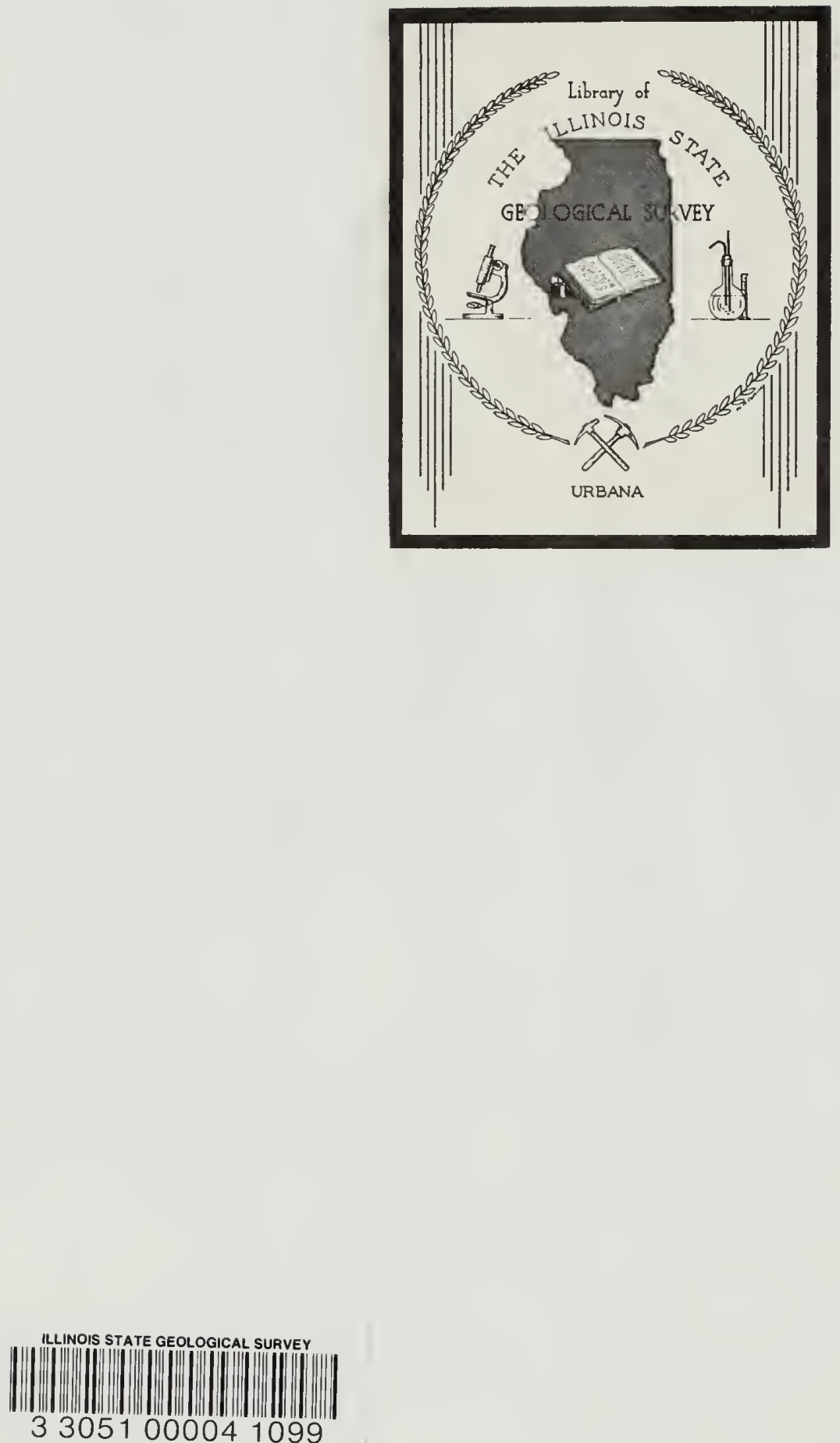


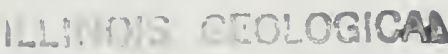 \\ SUNA IIBRARY \\ Miní $2: 1986$
}

\section{WISCONSINAN MOLLUSCAN FAUNAS OF THE ILLINOIS VALLEY REGION}

\author{
A. Byron Leonard and John C. Frye
}

\begin{abstract}
In the Illinois Valley region, the Altonian Substage (between 50,000 and 70,000 to 28,000 B.P.), Farmdalian Substage $(28,000$ to 22,000 B. P.), and Woodfordian Substage $(22,000$ to 12,500 B. P.) of the Wisconsinan Stage are represented by loess, water-laid clastics, and glacial till. Molluscan faunas of these sediments are here listed both geographically and stratigraphically, and 61 species are illustrated. Woodland faunas distinctive of the Roxana silt (Altonian) are found at 11 localities. Two of the Farmdalian localities yielded aquatic faunas and one woodland fauna. Faunas characteristic of the Woodfordian are abundant but differ in the various geographic areas. The faunas of the several Woodfordian rock-stratigraphic units are not distinguishable, but those of the three substages are distinctly so. During Wisconsinan time the glaciers did not produce rigorous climates in Illinois very far from the ice fronts. During Altonian and part of Farmdalian time the southern half of Illinois was heavily forested, but this was not so in Woodfordian time.
\end{abstract}

\section{INTRODUCTION}

Deposits of glacial till and associated outwash, loess, and alluvium of Wisconsinan age are the surficial materials of a large part of Illinois and thereby determine to a considerable extent the character of the soils, affect the occurrence of ground-water supplies, and pose problems for engineering construction. Consequently, in order to enable more precise recognition and better comprehension of these materials and their relationships, the Illinois State Geological Survey has been investigating the nature of these sediments, conducting fundamental studies of their mineralogy, stratigraphy, and content of fossil mollusks. This report deals with fossil mollusks and is integrated with Illinois Geological Survey studies of the stratigraphy of the deposits and with radiocarbon determinations of their age made by the United States Geological Survey.

For the most part the fossils reported on were collected from the loesses, but some were taken from terrace deposits, outwash sands, and silt and sand inclusions within glacial till. The geographic distribution of the faunal localities and geologic sections are shown in figure 1 . 


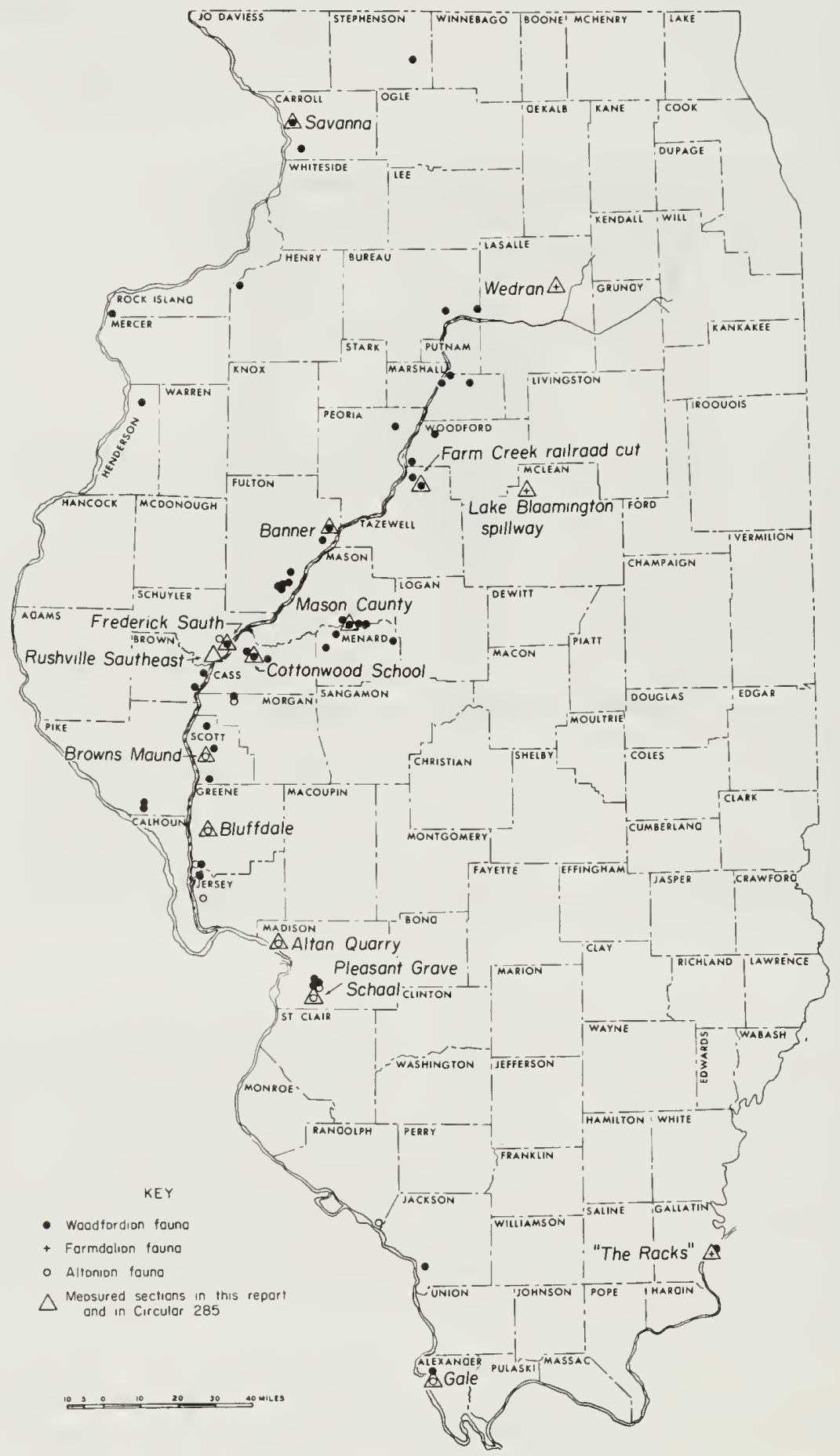

Fig. 1 - Collecting localities of molluscan faunas from Wisconsinan deposits in Illinois, and locations of measured geologic sections. 
George E. Ekblaw and H. B. Willman of the Illinois Geological Survey, and Paul R. Shaffer of the University of Illinois assisted in the field and in making stratigraphic interpretations. All radiocarbon dates referred to were determined in the Washington, D. C., laboratory of the United States Geological Survey.

\section{STRATIGRAPHY OF FOSSILIFEROUS UNITS}

The Wisconsinan Stage in the Lake Michigan glacial lobe recently has been discussed and reclassified by Frye and Willman (1960), and their rock-stratigraphic and time-stratigraphic terminology is used in this report.

The molluscan faunas described herein were collected from deposits included within the Altonian, Farmdalian, and Woodfordian Substages of the Wisconsinan glacial stage. In radiocarbon years the time span of these substages started between 50,000 and 70,000 years before present (B.P.) and extended to 12,500 years before present.

\section{Altonian Substage}

All the loess of Altonian age is included in the Roxana silt (Frye and Willman, 1960). The Pleasant Grove School section, which occurs in the bluffs of the Mississippi River valley in Madison County, Illinois, was designated as the type section of the Roxana. Roxana silt is described in 7 of the 11 measured geologic sections included with this report.

In the thick sections along the valley bluffs the Roxana silt contains at least five distinctive stratigraphic units. At some localities the base of the Roxana is colluvium, consisting of silt locally containing sand and pebbles like those in the underlying deposits. The basal colluvium, where observed, is noncalcareous and nonfossiliferous; it is in sharp contact with the beds below but is gradational with the overlying deposits.

The second unit of the Roxana is commonly a gray, massive, noncalcareous and nonfossiliferous silt. Locally this zone may contain sand (Browns Mound section) or sandy silt, and in some places (Pleasant Grove section) it is marked at the top by a humic streak, or an A-C soil profile. Both of the two lower units of the Roxana may or may not be present in a particular exposure, they are not generally loess, and they are clearly separable from the three higher units.

The third unit of the Roxana is light to dark pink, massive, coarse loess, and contains fossil snails in the upper part. The carbonate content is largely dolomite, and the zone is gradational with the overlying deposits. In some exposures the pink color diminishes upward and the upper part of the zone consists of interstratified pale pink and yellow-tan loess.

The fourth unit generally is gray-tan to yellow-tan, calcareous, fossiliferous loess. At many places it contains lenticular streaks of tan sand and coarse silt and locally may be quite sandy. The top of this zone is commonly gradational with the fifth, or uppermost, unit of the Roxana.

The fifth unit of the Roxana is pink-tan, massive loess. Commonly it is noncalcareous in the upper part and dolomitic and fossiliferous in the lower part, but at some places it is weakly calcareous throughout. Although the contact at the top of the Roxana generally is sharp, it is not strikingly apparent in many exposures because of the absence of a B-zone in the leached material in the upper few feet. 
The foregoing descriptions apply to the internal stratigraphy of the Roxana silt only where it is thick, near the bluffs of the Illinois, Sangamon, and Mississippi River valleys. East of these valleys it thins rapidly (much more rapidly than the overlying Peoria loess), becomes leached throughout, and its internal subdivisions are not recognizable.

The geographic distribution of thick, fossiliferous Roxana silt is significant. It occurs from the region just above the mouth of the Sangamon River southward along the Illinois River valley and the Mississippi River valley below the mouth of the Illinois. It is absent farther north along the Illinois River valley, but is exposed along the Sangamon River valley eastward to the mouth of Salt Creek and for a considerable distance up Salt Creek valley. This distribution pattern suggests that outwash in the pre-Shelbyville course of the Illinois River was the source of the loess that constitutes the Roxana silt.

\section{Farmdalian Substage}

The Farmdale silts are the deposits next younger than the Roxana. The original type area (Leighton, 1948) is retained. The unit is well exposed in the Farm Creek railroad cut section (Frye and Willman, 1960). The Farmdale generally consists of noncalcareous silt, massive to laminated, pinkish brown to pale purple; it characteristically contains humic or woody material (Banner section). In some places it is very peaty and in some places is a compacted mass of twigs and limbs of trees. Although locally it may be in part or entirely ("The Rocks" section) eolian loess, it is thought to consist largely of silts derived by wash from the older Roxana and earlier deposits. In some places (Wedron section) the Farmdale silts were deposited in ponded water and are fossiliferous and somewhat calcareous. However, even in such places they retain the characteristic plant material and predominant composition of silt.

\section{Woodfordian Substage}

The loesses of the Woodfordian Substage that occur above the Farmdale silts have been classed in three rock-stratigraphic units: the Morton loess, the Peoria loess, and the Richland loess (Frye and Willman, 1960). Beyond the Shelbyville moraine, which marks the outermost extent of Woodfordian glaciers, the loess of this substage is not readily subdivisible on lithologic evidence and therefore is all classed together as Peoria loess. Peoria loess is described in 9 of the 11 measured geologic sections included with this report. It consists of tan to yellowtan, massive, calcareous, fossiliferous silt. In some places along the major valley bluffs (Browns Mound section) it contains lenticular masses of sand and is indistinctly bedded, generally with the bedding inclined away from the valley bluff line (Cottonwood School section; Bluffdale section). Where the Peoria loess is quite thick and well exposed it commonly contains incipient soils, or humic streaks, in the mid-portion and higher (Frederick South section; Cottonwood School section and exposures one mile east; exposures at Peters). One of the incipient soils included within the Peoria loess was described by de Heinzelin (1959, p. 271). Although the color contrast, partial leaching, and small secondary nodules of $\mathrm{CaCO}_{3}$ make these minor soil zones conspicuous in some exposures, a recognizable B-zone has not so far been found associated with them. In a few exposures as many as half a dozen humic streaks have been observed in the upper part of the Peoria loess. 
Away from its major valley source, the Peoria loess thins more gradually than does the Roxana (Smith, 1942), but generally within a few miles of the valley bluff it becomes leached and nonfossiliferous. Although the internal subdivisions of the Roxana become indistinguishable within a relatively short distance of the major valleys, differentiation of the Peoria loess from that of the Farmdale and Roxana is possible far from the source valleys, even where the total loess section has become thin and is completely leached.

Within the limits of the Shelbyville moraine, the Woodfordian loess that occurs stratigraphically below the Shelbyville and younger tills and above the Farmdale silts is called the Morton loess. The Morton is a calcareous to weakly calcareous, massive, sparsely fossiliferous, gray to gray-tan, thin loess. It is clearly distinguishable from the noncalcareous, dark, humic to peaty Farmdale silts below and the glacial till above. No evidence of weathering has been observed at its top, and the stratigraphic relations, as well as carbon-14 dates, demonstrate its conformability with the overlying Woodfordian till. It is equivalent in age to, and stratigraphically continuous with, the lowermost part of the Peoria loess.

Loess overlies the Woodfordian tills along the Illinois River valley from the Peoria area where the Shelbyville moraine crosses the valley northeast to Grundy County. The loess, which is equivalent in age to, and stratigraphically continuous with, the upper part of the Peoria loess, has been named the Richland loess (Frye and Willman, 1960). It is tan to gray-tan, massive silt, calcareous below the surface soil profile, and commonly fossiliferous where it is calcareous. It rests on calcareous glacial till that shows no evidence of weathering at the top, and in general becomes progressively thinner up the valley as the underlying Woodfordian till sheets become progressively younger. The Richland loess thins away from the valley bluffs, and fossiliferous deposits are limited to relatively narrow belts adjacent to the valley.

Several molluscan faunas are listed from silts interbedded with glacial till (Lake Bloomington Spillway section), from included masses of sands and silts within glacial till, and from terrace deposits. However, it is not our purpose here to redescribe the stratigraphy of the many Wisconsinan glacial pulses. In such cases stratigraphic terminology is that in accepted use by the Illinois State Geological Survey and documented in many Survey publications.

\section{RADIOCARBON DATES OF FAUNAS}

All of the Wisconsinan faunas described here are correlated with a time scale based on carbon-14 dates determined in the Washington, D. C., laboratory of the United States Geological Survey (Frye and Willman, 1960). Thus the biostratigraphic zones defined by the faunal assemblages also may be referred to in terms of isotopically determined years. Dates ranging from $37,000 \pm 1500$ (W-869) to $17,100 \pm 300(\mathrm{~W}-730)$ were determined directly on shells collected from these faunal zones, but a much larger number of dates have been determined on wood from the beds that contain the shells and from beds above and below the fossil zones.

Snail shells from the Roxana silt have been dated at 37,000 \pm 1500 (W-869) at the Gale section and at 35,200 \pm 1000 (W-729) at the Pleasant Grove section. As the fossil zone within the Roxana is restricted approximately to its midportion, these two dates are judged to give a satisfactory indication of its age. On the basis of these dates, it seems reasonable that a range of radiocarbon years of 32,000 to $40,000 \mathrm{~B}$. P. would include all of the elements of this fauna in Illinois. 
The Farmdale silt is the most extensively dated stratigraphic unit in the Pleistocene of Illinois, but at only two localities has an adequate molluscan fauna been obtained. At the Wedron Quarry section a date of $26,800 \pm 700(\mathrm{~W}-871)$ was determined on flecks of wood associated with the shells, and earlier a date of $24,000 \pm 700(W-79)$ had been determined on a sample of wood from the immediately overlying bed. At "The Rocks" section, southeast of the Shawneetown bridge across the Ohio River, a date of $22,200 \pm 450$ (W-867) was obtained on the shells. The time span of the Farmdalian is judged to extend from 28,000 to 22,000 B. P.

Dates related to the age of the fauna from the Morton loess have been reported from the vicinity of the Farm Creek section where wood dates of $20,340 \pm$ $750(W-349)$ and $20,700 \pm 650(W-399)$ have been obtained. Although in general not directly associated with faunal localities, there are a large number of dates from the Farmdale silts below the Morton loess and a few dates from the Shelbyville till above it. The available dates indicate a range in radiocarbon years of 20,000 to 22,000 for this faunal zone.

Beyond the limits of the Shelbyville moraine, the Peoria loess includes deposits and faunas that are equivalent in age to the Morton loess, the overlying Woodfordian till, and the Richland loess. Two radiocarbon dates have been determined from the snail shells of this fauna; they are $20,300 \pm 400(W-870)$ from the Enion area (Fulton County), and 17,100 \pm 300 (W-730) from the Burdick Branch exposures north of the Pleasant Grove section. In addition, several dates determined on wood have direct relation to the age of the fauna of the Peoria loess. Wood from immediately below the fossiliferous loess in the Enion area has been dated 23,500 \pm $400(W-745)$, and this agrees well with the date of 20,300 determined on shells from the upper part of the overlying loess. No radiocarbon dates have been obtained directly from the Richland loess, but wood from fossiliferous terrace deposits in Fulton County has been dated $15,600 \pm 600(\mathrm{~W}-381)$. From these data it appears that the age of the molluscan fauna of the Peoria loess, and its stratigraphic equivalents, ranges from approximately 22,000 to approximately 15,000 radiocarbon years before the present.

Several anomalous dates do not properly fit the patterns developed by the majority of the dates. It will be noted that in the Lake Bloomington Spillway section an upper date is listed as greater than $34,000(W-67)$, whereas a date from wood lower in the section is reported as 31,000 or older $(W-186)$. This anomaly is as yet unexplained. A date determined on shells from the Peters exposures, north of the Pleasant Grove section, is reported at $27,500 \pm 900(W-868)$, which is 5,000 to 10,000 years younger than would be anticipated for Roxana faunas in the area. The sample of shell material that was dated from this exposure was collected by several persons on several visits, and it is judged that a small quantity of shell material from the overlying Peoria loess (dated 17,100 $\pm 300[\mathrm{~W}-730]$ at the Burdick Branch exposures a third of a mile to the south) was intermixed in the sample, which could easily account for the discrepancy.

\section{FOSSIL MOLLUSCAN FAUNAS}

Recent revision of the classification of the late Pleistocene deposits in Illinois has produced the framework necessary for a systematic study of fossil molluscan faunas associated with the stratigraphic units currently assigned to the Wisconsinan Stage. Knowledge of the relative ages of many units, derived from radiocarbon dates, stratigraphic position, and relationship of moraines to the fossil- 
bearing deposits, has enabled us to elaborate criteria for the recognition of faunas characteristic of the several Wisconsinan substages. Assignment of assemblages to specific substages makes it possible to recognize within reasonable limits the variations and discrepancies produced by local ecological conditions, geographic differences, and hazards of random sampling. It allows a greater degree of assurance in correlating the fauna contained in sediments at localities where the relative age has not been determined by any other method. Bulk samples were processed from most of the approximately 60 localities shown in figure 1. Experience has shown, however, that repeated bulk sampling is required in order to approach full recovery of an assemblage. In one instance, pooling of two bulk samples taken at the same locality at different times resulted in a 30 percent increase in the total number of species recovered, although each sample contained more than 200 identifiable specimens. Therefore, claim can not be made for more than reasonable completeness of the snail collections discussed here.

Before focusing attention on the fossil mollusks discussed in this paper, it seems appropriate to review the complex factors that influence the composition of local faunal populations. Aside from the distortions induced by random and inadequate sampling and by the vagaries of preservation, assemblages of fossil organisms reflect the combined and interacting effects of a wide variety of forces upon the formerly living populations. Among these, perhaps the most obvious, if not always the most important, are changing climates, local ecological conditions, including details of sedimentation, and the relative genetic stability of the organisms involved.

Climatic changes occur constantly (if sometimes slowly) under the influence of numerous complex factors, and such changes keep the living organism in a perpetual state of nonequilibrium with its environment. The frequency and distribution of precipitation, the total annual precipitation, and the evaporation rate are of paramount importance to any animal or plant. Average temperatures and diurnal and seasonal temperature extremes impose stresses upon the organism and make necessary continual adjustments. Regional long-range climatic changes related to orogeny, changes in mean sea level, fluctuations in the prevailing patterns of air-mass movements, or other changes are additional hazards to survival. Climatic differences related to latitude or altitude and cyclic climatic changes coincident with repeated continental glaciation constitute environmental stresses to which the organism must adapt or succumb, or from which it must escape by migration.

Local ecological conditions are notedly variable. Soils, important elements of local environment, vary with parent materials, maturity, vegetative cover, and relative position in the microtopography. Availability of appropriate food and cover, inter- and intra-specific competition, and selective predation produce profound effects upon animal populations. Moreover, small and sedentary animals, such as gastropods, utilize microhabitats that may be considerably at variance with the general environmental pattern of a region, making analysis of their precise ecological requirements extremely difficult.

Faunal change is not necessarily related to the physical separation of two stratigraphic levels, but rather to the time that elapsed during their deposition and to the concomitant ecological changes involved. These are the factors that provide opportunities for the mutations, genetic drift, extinctions, or mass migrations of organisms that serve to alter the composition of populations. Populations at different stratigraphic levels do not necessarily differ greatly, especially when the amount of time involved is relatively small, provided that the ecological conditions are reasonably similar. 
Finally, the composition of successive populations is profoundly influenced by the relative genetic stability of the organisms under consideration. The Mollusca seem to have long since passed the peak of their adaptive radiation and, when compared with many other kinds of animals, to have reached a high degree of genetic stability. Although there is ample evidence that terrestrial and fresh-water mollusks are still making evolutionary progress, their genetic conservatism and the brief interval of time involved suggest that faunal changes within the Wisconsinan result from migrations in response to fluctuating ecological conditions.

These considerations lead to the conclusion that assemblages of fossil mollusks at any stratigraphic level may have distinctive character over a considerable area if the ecological conditions are similar and relatively stable. The speciescomposition of a fauna may comprise well known taxa, found perhaps in younger and in older rocks. Distinctive qualities of a specific assemblage need not include extinctions, the presence of newly evolved taxa, or even so-called "index-fossils"; as we have pointed out, nearly identical assemblages may reappear from time to time in the stratigraphic column without nullifying their significance and usefulness at any specific stratigraphic level. All molluscan fossils considered in this report are housed in the paleontological collections of the Illinois State Geological Survey.

\section{Altonian Faunas}

Altonian molluscan faunal assemblages are shown in figure 2, in which 10calities of occurrence are arranged geographically, and a summary of Altonian occurrences appears on figure 3, in which relationships between Altonian and other Wisconsinan faunal assemblages are shown.

Inasmuch as Altonian faunas have been recovered only from the Roxana silt, it is not surprising that the northernmost locality of occurrence should be in extreme southeastern Schuyler County (locality 29). Ten additional localities are distributed southward to Alexander County (locality 58b). As the Roxana silt generally thickens southward, there is a corresponding increase in the variety of species as well as in density of the local populations in the southern localities. This effect can be attributed to at least two factors: improved preservation of shells in the thicker deposits and probably more favorable ecological conditions in the south, where the forests were denser and more stable.

A total of 28 species of mollusks are known to occur in the Roxana silt, although the average local fauna comprises no more than half this number. Among these, six species, Anछuispira alternata, Haplotrema concavum, Hendersonia occulta, Stenotrema fraternum, S. hirsutum, and Succinea ovalis, are found in all three of the Wisconsinan substages - Altonian, Farmdalian, and Woodfordian. Eighteen species, including Cionella lubrica, Discus cronkhitei, D. macclintocki, Gastrocopta armifera, G. contracta, Halvaiin minuscula. Helicodiscus parallelus, Mesodon thyroidus, Pomatiopsis scalaris, Punctum minutissimum, Retinella electrina, Strobilops labyrinthica, Succinea gelida, S. छrosvenori, Vallonia gracilicosta, V. parvula, Vertigo hubrichti (not shown on fig. 2), and Zonitoides arboreus occur in Altonian and Woodfordian deposits but have not been found in sediments of Farmdalian age. Two species, Allogona profunda and Anguispira kochi, range from Altonian into Farmdalian deposits, but have not been recovered from Woodfordian sediments. Only two species, Triodopsis hubrichti and T. altonensis, seem clearly restricted to the Altonian. Allogona profunda also is restricted to the Altonian except for its occurrence in the Farmdalian at the Shawneetown locality (57b). 
Despite the small number of species restricted to the Altonian, the assemblage is distinctive and easily recognizable even in the field, inasmuch as the most characteristic species are of large size and most of them occur consistently at most localities. Triodopsis altonensis and Allogona profunda, both easily recognized, occur most consistently at all of the eleven Altonian localities studied. Although apparently restricted to the Altonian, Triodopsis hubrichti does not occur frequently enough to make it of significant value in faunal characterization. Anguispira alternata also is a conspicuous member of the Altonian assemblage although it ranges throughout the Wisconsinan in the area under consideration. Like Allogona profundn, it occurs at each of the eleven localities studied.

\section{Ecological Considerations}

The characteristic Altonian molluscan fauna is typical of those occurring in well established hardwood forests, an observation confirmed by the abundance of Anguispira kochi at some localities. Of A. kochi Goodrich (1932, p. 35) says: "... one of the typical mollusks of old forests, and seldom found even in thick second-growth timber. It hides during the hours of bright days under rotting logs and decaying leaves." Of the habits of Triodopsis altonensis nothing is known, but because of its close genetic relationship with $T$. multilinenta it may be inferred that it lived in especially humid portions of forests or forest borders. T. multilineata has been observed living in heavily forested Missouri River bluff situations in northeastern Kansas, where contact springs along beds of shale keep fallen leaves and leaf-mold constantly wet. Allogona profunda also is a species of the deep forest, and at many stations occurs with T. altonensis, Succinea ovalis, and Baplotrema concavum along wooded bluff lines. The relation of Anguispira alternata to woodlands also is well known, but this species often inhabits forest borders under relatively small shrubs.

The association of Anछuispira alternata, A. kochi, Allogona profunda, Stenotrema fraternum, S. hirsutum, Succinea ovalis, Triodopsis hubrichti, and T. altonensis presents a paleoecological picture of a well watered, heavily forested bluff-line habitat, which in Altonian time was receiving heavy deposits of loess. None of the remaining species in the total Altonian assemblage serves to alter this picture, although some species, such as Hendersonia occulta and Pomatiopsis scalaris, occurred along stream banks and on low floodplain habitats, and many species, such as Gastrocopta armifera, Hawaila minuscula, and Helicodiscus parallelus may occur in open prairie situations as well as in woodlands.

The extremely rare occurrence of some typically woodland species, including Cionella lubrica, Strobilops labyrinthica, and Zonitoides arboreus is unexplained.

\section{Taxonomic Considerations}

Inasmuch as the shells known asTriorlopsis fosteri hubrichti Baker and T. multilineata altonensis Baker are distinctive enough to be readily recognized, and as each is, so far as known, separated from its typical species by a time, rather than a geographical interval, each is here treated as a full species, and they are called $T$. hubricht $i$ and $T$. altonensis. In a later section, the gastropod described by Baker as Vertigo gouldi hubrichti, for the same reasons, is calledVertigo hubrichti. The same is true of Triodopsis multilineata algonquinensis Nason, herein called Triodopsis algonquinensis. 


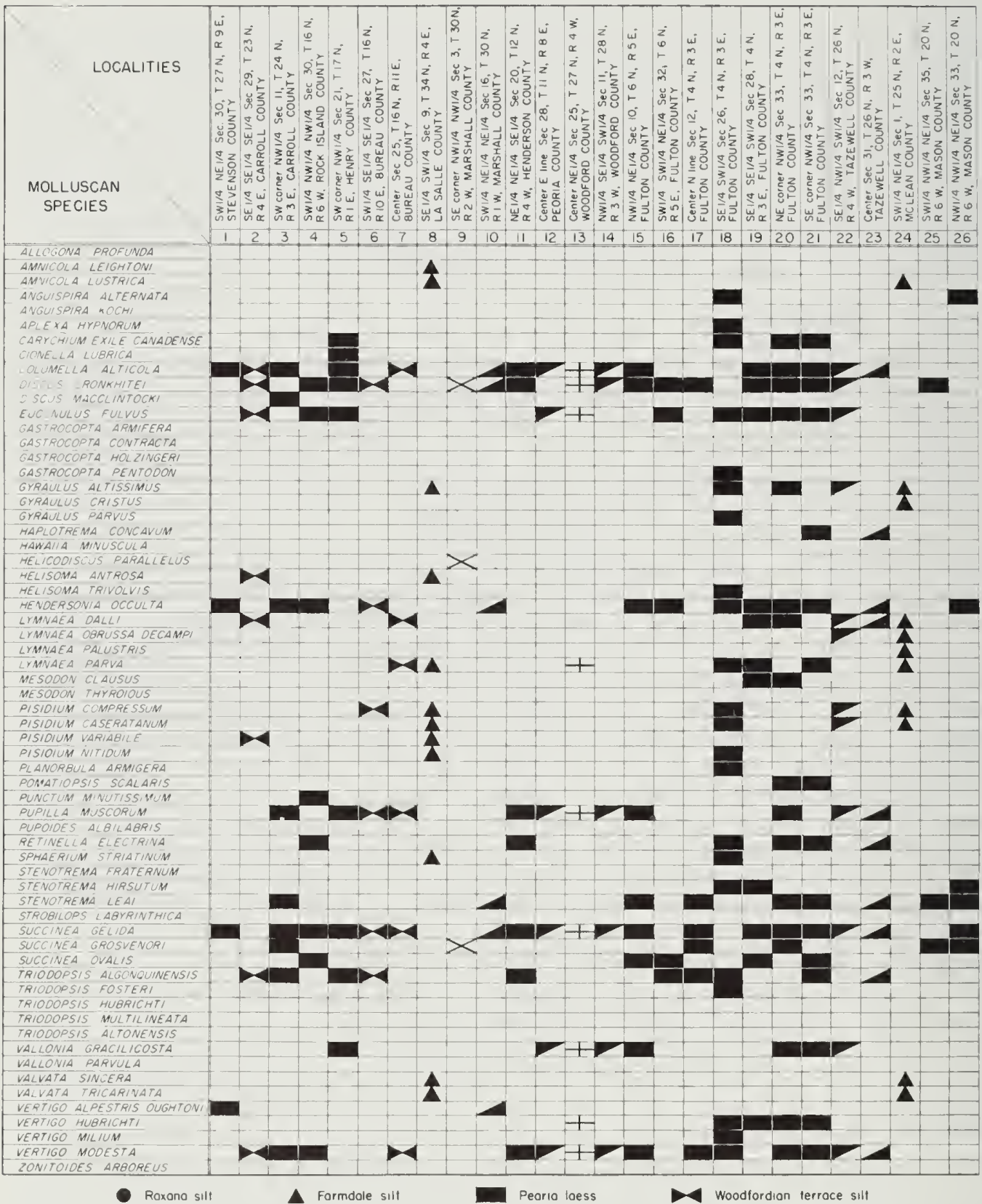

Fig. 2 - Chart showing localities from which Wisconsinan molluscan faunas were cera from Peoria loess at locality 30; 2) Pisidium obtusale from Lake Bloom- 


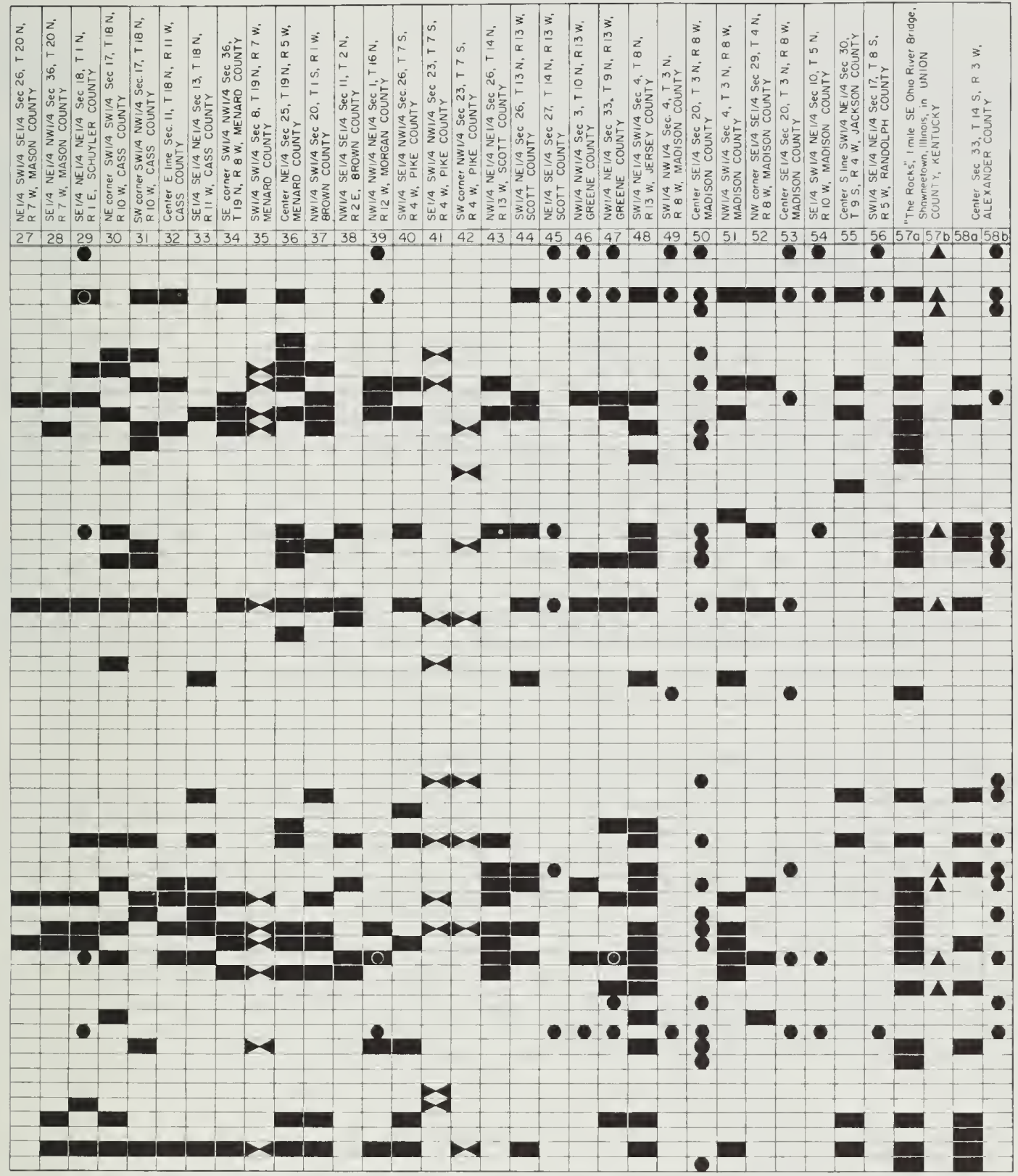

4 Mortan laess Richland laess $\quad$ Narmal marane $\quad$ Metamara maraine

collected. The chart does not show the following species: 1) Gastrocopta proington silt at locality 24; 3) Sphaerium occidentale from Peoria loess at locality 18. 
Succinea grosvenori gelida of Baker, although it occurs at many places with Succinea grosvenori Lea, has nowhere been observed to intergrade with the kind of shell here treated as acceptable grosvenori, and is likewise treated as a full species and called Succinea gelida. It should be remarked that the names Succinea gelida and $S$. grosvenor $i$ are here used in the sense of "form" species, inasmuch as it is virtually impossible to distinguish many species of Succineidae from the shells alone. It is therefore difficult to assess the value and significance of the variations seen. Wayne's (1959, p. I1) remark, "Only... Succinea gelida is known at this time to have stratigraphic application in Indiana," probably reflects the difficulties entailed in distinguishing among different species of the smaller kinds of Succinea and related genera.

\section{Farmdalian Faunas}

Farmdalian molluscan faunas in the area under consideration are not yet well characterized. Only three localities $(8,24,57 \mathrm{~b})$ are known, and each of these is atypical in some manner or other. Locality 8 (the Wedron section) exposes, among other sediments, 25 feet of dark gray silt with some clay and sand streaks from which an abundant molluscan fauna was recovered. A radiocarbon date in the upper third of this unit clearly places the deposit well within the Farmdalian, but the fauna, composed exclusively of aquatic species, does not present a complete picture of the total assemblage living in the area at the time.

The collections from the Lake Bloomington Spillway section (locality 24) have been referred to the Farmdalian fauna because of their general resemblance to those at the Wedron Quarry section and in spite of two contradictory radiocarbon dates.

The third locality (57b, "The Rocks" section), judged by lithological relation s and radiocarbon years $(22,200 \pm 450$; $W-867)$, is transitional between the Farmdalian and Woodfordian substages, but the mollusks contained in bed 4 of the geologic section are so unlike those in the overlying Peoria loess that they are assigned to the Farmdalian assemblage. The fauna here bears a strong resemblance to that of the Altonian, but differs in the presence of Triodops is fosteri rather than $T$. hubricht $i$, and in the predominance of Anguispira kochi, which is relatively rare in Altonian deposits. For reasons not readily apparent, almost all the species here are represented by individuals that are larger than usual, each approaching or occasionally exceeding the upper limits of the ordinary range in size. This observation is especially true of Allogona profunda, Anguispira alternata, and $A$. kochi.

With these reservations, the Farmdalian molluscan fauna as now known from these localities consists of 24 species. Six of these, Anguispira alternata, Haplotrema concavum, Hendersonia occulta, Stenotrema fraternum, S. hirsutum, and Succinea ovalis range from Altonian through the Woodfordian Substages; in fact they are generally more abundant in Woodfordian deposits than they are now known to be in the Farmdalian. A second group of species, including Gyraulus altissimus, Lymnaea dalli, L. obrussa decampi, L. parua, Helisoma antrosa, Pisidium compressum, P. caseratanum, Triodopsis fosteri, andValvata tricarinata are known to occur in Woodfordian and Farmdalian assemblages. Two species, Allogona profunda and Anguispira kochi, occur in the Altonian as well as the Farmdalian but have not been seen in Woodfordian collections in the area under consideration.

Finally, a group of species, conspicuous among which is Amnicola leightoni, A. lustrica, Gyraulus cristus, Lymnaea palustris, Sphaerium striatinum, and Valvata sincera found only in Farmdalian faunas. 


\section{Ecological Considerations}

Although the limited number and erratic geographical distribution of available Farmdalian fossiliferous localities restrict generalizations about ecological conditions during Farmdalian time, a few observations seem pertinent. "The Rocks" section (locality $57 \mathrm{~b}$ ) reveals a woodland fauna of the type found in well established hardwood forests. It would appear that the heavy forests of Altonian time persisted through the Farmdalian Substage until the beginning of, or perhaps slightly into, earliest Woodfordian time, at least in southern Illinois. There is no evidence of heavy forest cover in northern Illinois at any time during the Wisconsinan Stage.

The abundance of Anguispira kochi and the robust individuals of Allogona profunda, Anguispira alternata, and Succinea ovalis confirm the concept of deep forests at the southern locality at the time the shells were buried in the loess. It is evident that the terrain was well watered, but there is little to indicate that the climate was anything more than slightly cooler than at present.

The absence of terrestrial species in the two northern localities $(8,24)$ does not permit speculation concerning vegetational cover of the uplands of this part of Illinois in Farmdalian time. There is reason, however, to doubt the occurrence there of forest cover, because it seems likely that the large shells of forest species would almost certainly have found their way into pond deposits. All that can be conjectured is the presence of permanent, clear, ponded water at the sites from which the collections came. There is nothing to indicate that these waters were more than slightly cooler than lakes and ponds existing in the area today. Pending the discovery of fossiliferous upland Farmdalian silt, the terrestrial molluscan fauna (and a more complete paleoecological picture) of the Farmdalian Substage in the northern parts of Illinois must remain unknown.

\section{Woodfordian Faunas}

Woodfordian molluscan assemblages comprising an aggregate of 55 species have been recovered from a total of 50 localities; at some of them, Altonian or Farmdalian faunas occur in their proper stratigraphic positions. Of the total assemblage, 22 species were restricted to the Woodfordian. These include: Aplexa hypnorum, Carychium exile canadense, Columella alticola, Euconulus fulvus, Gastrocopta holzingeri, G. procera, G. pentodon, Gyraulus parvus, Helisoma trivolvis, Mesodon clausus, Pisidium nitidum, P. variabile, Planorbula armigera, Pupilla muscorum, Pupoides albilabris, Stenotrema leai, Triodopsis algonquinensis, T. multilineata,Vertigo alpestris oughtoni, V. milium, and V. modesta.

Woodfordian faunas are divided into several categories, based on whether they were recovered from Peoria loess, Morton loess, Richland loess, terrace deposits, or moraines (fig. 2).

\section{Faunal Assemblages from the Peoria Loess}

The Peoria loess, which includes all post-Farmdalian loessial deposits outside the borders of the Shelbyville moraine, comprises silts ranging in age throughout the Woodfordian Substage. This gray to gray-tan or grayish yellow silt is almost everywhere fossiliferous except where it has been leached. Fossil mollusks from the Peoria loess at 37 localities are here reported (fig. 2); the number could be increased almost indefinitely by additional collections. 


\section{PLATE 1}

\section{LARGE TERRESTRIAL GASTROPODS FROM WOODLAND ASSEMBLAGES}

All figures approximately natural size

Figs. A, B, C. - Mesodon clausus (Say); spiral, apertural, and umbilical views, respectively. Peoria loess, North Enion section, SE $\frac{1}{4} \operatorname{SE} \frac{1}{4} \operatorname{SW} \frac{1}{4} \sec .28$, T. 4 N., R. 3 E., Fulton County.

Figs. D, E, F. - Triodopsis fosteri(Baker); spiral, a pertural, and umbilical views, respectively. Peoria loess, Gale section, center sec. 33, T. 14 S., R. 3 W., Alexander County.

Figs. G, H, I. - Triodopsis hubrichti Baker; umbilical, apertural, and spiral views, respectively. Roxana silt, Gale section, center sec. 33, T. 14 S., R. 3 W., Alexander County.

Figs. J, K, L. - Anguispira alternata (Say); umbilical, a pertural, and spiral views, respectively. Roxana silt, Gale section, center sec. 33, T. 14 S., R. 3 W., Alexander County.

Figs. M, N, O. - Mesodon thyroidus (Say); spiral, apertural, and umbilical views, respectively. Roxana silt, Peters section, SW $\frac{1}{4}$ NW $\frac{1}{4}$ sec. 4, T. 3 N., R. 8 W., Madison County.

Figs. P, Q, R. - Triodopsis algonquinensis Nason; spiral, apertural, and umbilical views, respectively. Peoria loess, SW $\frac{1}{4}$ NE $\frac{1}{4}$ SW $\frac{1}{4}$ sec. 4, T. 8 N., R. 13 W., Jersey County.

Figs. S, T, U. - Allogona profunda (Say); umbilical, spiral, and apertural views, respectively. Roxana silt, Gale section, center sec. 33, T. 14 S., R. 3 W., Alexander County.

Figs. V, W, X. - Triodopsis altonensis Baker; spiral, apertural, and umbilical views, respectively. Roxana silt, Pleasant Grove section, center SE $\frac{1}{4} \mathrm{sec}$. 20, T. 3 N., R. 8 W., Madison County.

Figs. AA, BB, CC. - Anछuispira kochi (Pfeiffer); spiral, apertural, and umbilical views, respectively. Roxana silt, Gale section, center sec. 33, T. 14 S., R. 3 W., Alexander County.

Fig. Y. - Succinea ovalis Say; a pertural views. Peoria loess, SW $\frac{1}{4}$ NE $\frac{1}{4}$ SW $\frac{1}{4}$ sec. 4, T. 8 N., R. 13 W., Jersey County. 

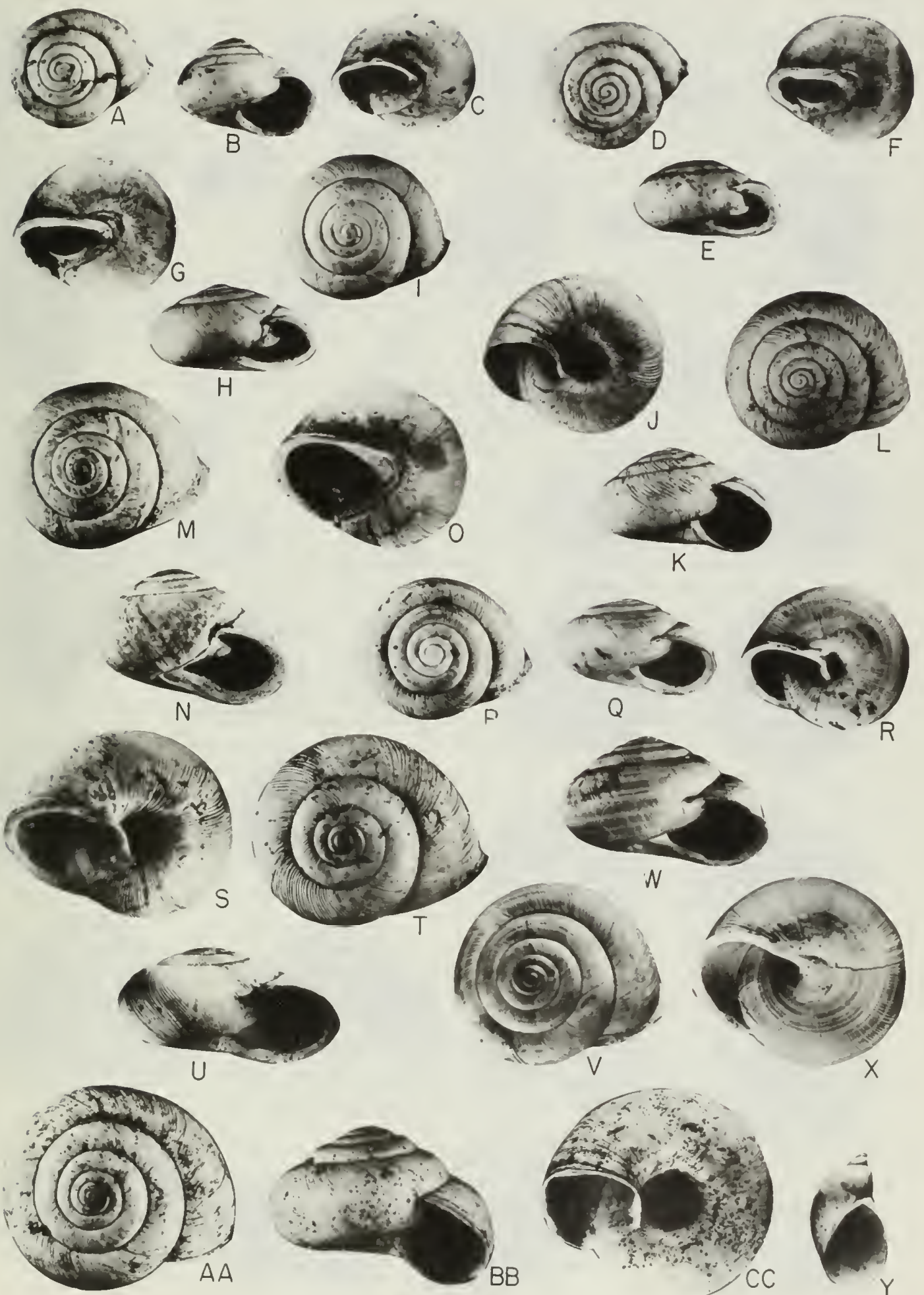


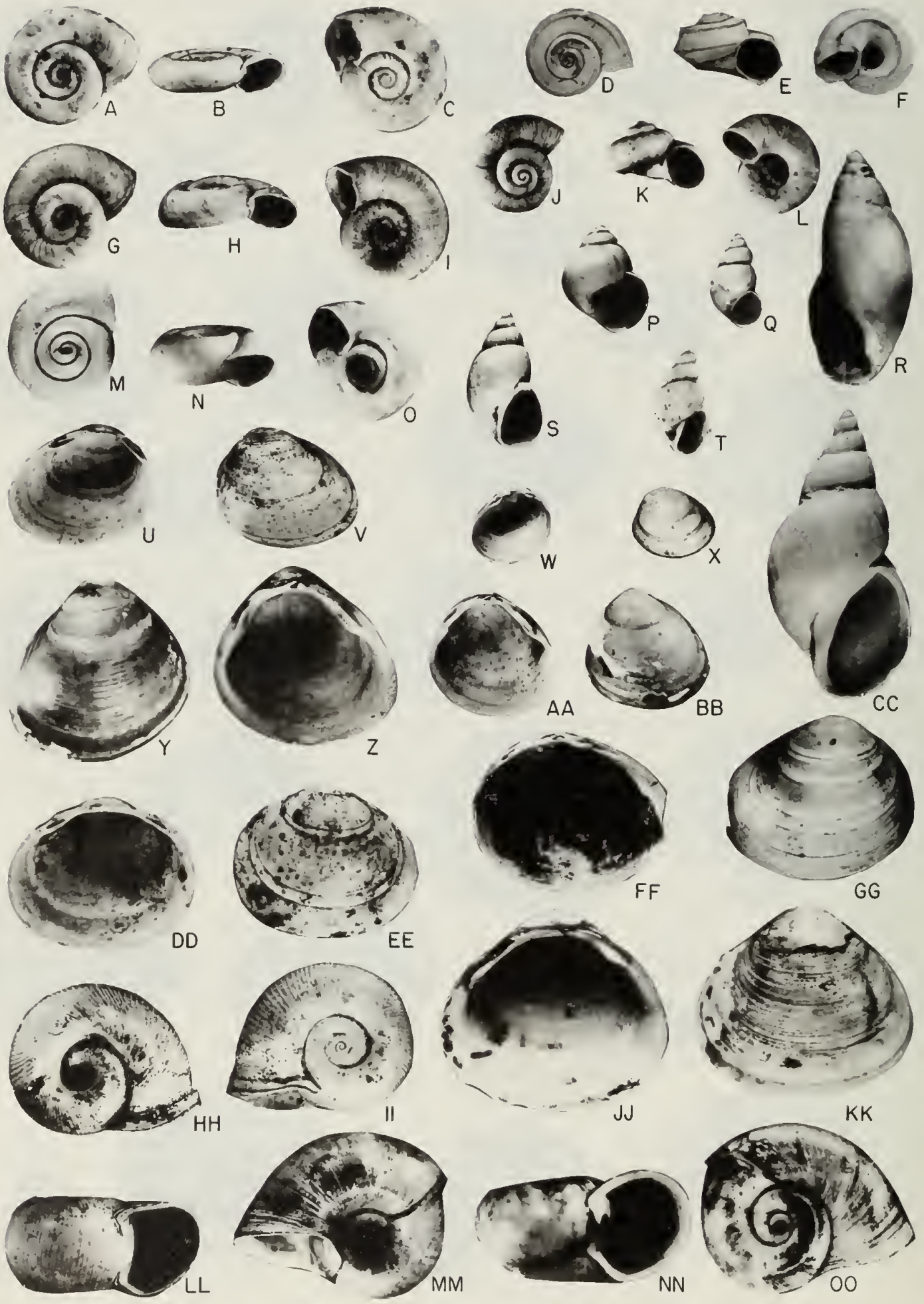




\section{PLATE 2 \\ AQUATIC GASTROPODS AND SPHAERID FRESH-WATER MUSSELS \\ Various magnifications}

Figs. A, B, C. - Gyraulus parvus (Say); spiral, apertural, and umbilical views, respectively. Basal zone of Peoria loess, SE $\frac{1}{4} \mathrm{SW} \frac{1}{4} \mathrm{sec} .26, \mathrm{~T} .4 \mathrm{~N} ., \mathrm{R}$. 3 E., Fulton County. Enlarged approximately $5 X$.

Figs. D, E, F. - Valvata tricarinata(Say); spiral, apertural, and umbilical views, respectively. Farmdalian water-laid silts, Wedron Quarry section, SE $\frac{1}{4}$ SE $\frac{1}{4}$ SW $\frac{1}{4}$ sec. 9, T. 34 N., R. 4 E., La Salle County. Enlarged approximately $3 \frac{1}{2} \mathrm{X}$.

Figs. G, H, I. - Gyraulus altissimus Baker; spiral, apertural, and umbilical views, respectively. Farmdalian water-laid silts, Wedron Quarry section, SE $\frac{1}{4} \mathrm{SE} \frac{1}{4}$ SW $\frac{1}{4}$ sec. 9, T. 34 N., R. 4 E., La Salle County. Enlarged approximately $5 X$.

Figs. J, K, L. - Valuata sincera Say; spiral, apertural, and umbilical views, respectively. Farmdalian water-laid silts, Lake Bloomington Spillway section, SW $\frac{1}{4}$ NE $\frac{1}{4}$ sec. 1, T. 25 N., R. 2 E., McLean County. Enlarged approximately $4 \mathrm{X}$.

Figs. M, N, O. - Planorbula armigera (Say); spiral, apertural, and umbilical views, respectively. Basal zone Peoria loess, SE $\frac{1}{4}$ SW $\frac{1}{4}$ sec. 26, T. 4 N., R. 3 E., Fulton County. Enlarged approximately $4 \mathrm{X}$.

Fig. P. - Amnicola leightoni Baker; apertural view. Farmdalian water-laid silts, Wedron Quarry section, SE $\frac{1}{4}$ SE $\frac{1}{4}$ SW $\frac{1}{4}$ sec. 9, T. 34 N., R. 4 E., La Salle County. Enlarged approximately $4 \mathrm{X}$.

Fig. Q. - Amnicola lustrica (Say); a pertural view. Farmdalian water-laid silts, Wedron Quarry section, SE $\frac{1}{4}$ SE $\frac{1}{4}$ SW $\frac{1}{4}$ sec. 9, T. 34 N., R. 4 E., La Salle County. Enlarged approximately $4 \mathrm{X}$.

Fig. R. - Aplexa hypnorum (Linné); apertural view of incomplete specimen. Basal zone Peoria loess, SE $\frac{1}{4}$ SW $\frac{1}{4}$ sec. 26, T. 4 N., R. 3 E., Fulton County. Enlarged approximately $21 / 3 \mathrm{X}$.

Fig. S. - Lymnaea parva (Say); apertural view. Sandy silt inclusion in Metamora moraine, center NE $\frac{1}{4}$ sec. 25, T. 27 N., R. 4 W., Woodford County. Enlarged approximately $3 \frac{1}{2} \mathrm{X}$.

Fig. T. - Lymnaea dalli Baker; apertural view. Basal zone Peoria loess, Enion North section, SE $\frac{1}{2}$ SE $\frac{1}{2}$ SW $\frac{1}{2}$ sec. 28, T. 4 N., R. 3 E., Fulton County. Enlarged approximately $4 \mathrm{X}$.

Figs. U, V. - Pisidium nitidum (Mighels); internal and exterior views of right valve, respectively. Farmdalian water-laid silts, Wedron Quarry section, $S E \frac{1}{4} \mathrm{SE} \frac{1}{4}$ SW $\frac{1}{4}$ sec. 9, T. 34 N., R. 4 E., La Salle County. Enlarged approximately $6 \mathrm{X}$.

Figs. W, X. - Pisidium obtusale Prime; interior and exterior views of right valve, respectively. Farmdalian water-laid silts, Lake Bloomington Spillway section, SW $\frac{1}{4}$ NE $\frac{1}{4}$ sec. 1, T. 25 N., R. 2 E., McLean County. Enlarged approximately $6 \mathrm{X}$.

Figs. Y, Z. - Pisidium compressum Prime; exterior and interior views of right valve, respectively. Farmdalian water-laid silts, Wedron Quarry section, SE $\frac{1}{4}$ SE $\frac{1}{4}$ SW $\frac{1}{4} \sec .9$, T. 34 N., R. 4 E., La Salle County. Enlarged approximately $7 X$. 


\section{PLATE 2 - continued}

Figs. AA, BB. - Pisidium variabile Prime; interior and exterior views of right valve, respectively. Farmdalian water-laid silts, Wedron Quarry section, SE $\frac{1}{4} \mathrm{SE} \frac{1}{4}$ SW $\frac{1}{4} \sec .9$, T. 34 N., R. 4 E., La Salle County. Enlarged approximately $6 \mathrm{X}$.

Fig. CC. - Lymnaea palustris (Müller); apertural view. Farmdalian water-laid silts, Lake Bloomington Spillway section, SW $\frac{1}{4}$ NE $\frac{1}{4}$ sec. 1, T. 25 N., R. 2 E., McLean County. Enlarged approximately $2 X$.

Figs. DD, EE. - Sphaerium occidentale Prime; interior and exterior views of right valve, respectively. Basal zone Peoria loess, SE $\frac{1}{4} \mathrm{SW} \frac{1}{4}$ sec. 26, T. 4 N., R. 3 E., Fulton County. Enlarged approximately $3 \frac{1}{2} X$.

Figs. FF, GG. - Pisidium caseratanum (Polis); interior and exterior views of right valve, respectively. Farmdalian water-laid silts, Wedron Quarry section, SE $\frac{1}{4}$ SE $\frac{1}{4}$ SW $\frac{1}{4}$ sec. 9, T. 34 N., R. 4 E., La Salle County. Enlarged approximately $3 \frac{1}{2} \mathrm{X}$.

Figs. HH, II, LL. - Helisoma trivolvis (Say); umbilical, spiral, and apertural views, respectively. Basal zone Peoria loess, SE $\frac{1}{4}$ SW $\frac{1}{4}$ sec. 26, T. 4 N., R. 3 E., Fulton County. Enlarged approximately $21 / 3 X$.

Figs. JJ, KK. - Sphaerium striatinum (Lamarck); interior and exterior views of right valve, respectively. Basal zone Peoria loess, SE $\frac{1}{4} \mathrm{SW} \frac{1}{4} \mathrm{sec} .26, \mathrm{~T} .4 \mathrm{~N}$., R. 3 E., Fulton County. Enlarged approximately $2 \mathrm{X}$.

Figs. MM, NN, OO. - Helisoma antrosa (Conrad); umbilical, apertural, and spiral views, respectively. Farmdalian water-laid silts, Wedron Quarry section, SE $\frac{1}{4} \mathrm{SE} \frac{1}{4} \mathrm{SW} \frac{1}{4} \mathrm{sec}$. 9, T. 34 N., R. 4 E., La Salle County. Enlarged approximately $2 \frac{1}{2} \mathrm{X}$. 


\begin{tabular}{|c|c|c|c|}
\hline \multirow{2}{*}{ SPECIES } & \multicolumn{3}{|c|}{ WISCONSINAN SUBSTAGES } \\
\hline & ALTONIAN & FARMOALIAN & WOODFORDIAN \\
\hline \multirow{2}{*}{\multicolumn{4}{|c|}{$\begin{array}{l}\text { APLEXA HYPNORUM } \\
\text { CARYCHIUM EXILE CANADENSE }\end{array}$}} \\
\hline & & & \\
\hline \multirow{2}{*}{\multicolumn{4}{|c|}{$\begin{array}{l}\text { COLUMELLA ALTICOLA } \\
\text { EUCONULUS FULVUS }\end{array}$}} \\
\hline & & & \\
\hline \multicolumn{4}{|l|}{ GASTROCOPTA HOLZINGERI } \\
\hline \multicolumn{4}{|l|}{ GASTROCOPTA PENTODON } \\
\hline \multicolumn{4}{|l|}{ GYRAULUS PARVUS } \\
\hline \multicolumn{4}{|l|}{ HELISOMA TRIVOLVIS } \\
\hline \multicolumn{4}{|l|}{ MESODON CLAUSUS } \\
\hline \multicolumn{4}{|l|}{ PLANORBULA ARMIGERA } \\
\hline \multicolumn{4}{|l|}{ PUPILLA MUSCORUM } \\
\hline \multicolumn{4}{|l|}{ PUPOIDES ALBILABRIS } \\
\hline \multicolumn{4}{|l|}{ STENOTREMA LEAI } \\
\hline \multicolumn{4}{|l|}{ TRIODOPSIS ALGONOUINENSIS } \\
\hline \multicolumn{4}{|l|}{ TRIODOPSIS MULTILINEATA } \\
\hline \multicolumn{4}{|l|}{ VERTIGO ALPESTRIS OUGHTONI } \\
\hline \multicolumn{4}{|l|}{$\begin{array}{ll}\text { VERTIGO } & \text { MILIUM } \\
\text { VERTIGO } & \text { MODESTA }\end{array}$} \\
\hline \multicolumn{4}{|l|}{ ANGUISPIRA ALTERNATA } \\
\hline HAPLOTREMA CONCAVUM & & & \\
\hline HENDERSONIA OCCULTA & & & \\
\hline STENOTREMA FRATERNUM & & & \\
\hline STENOTREMA HIRSUTUM & & & \\
\hline SUCCINEA OVALIS & & & \\
\hline CIONELLA LUBRICA & & & \\
\hline DISCUS CRONKHITEI & & & \\
\hline DISCUS MACCLINTOCKI & & & \\
\hline GASTROCOPTA ARMIFERA & & & \\
\hline GASTROCOPTA CONTRACTA & & & \\
\hline HAWAIIA MINUSCULA & & & \\
\hline HELICOOISCUS PARALLELUS & & & \\
\hline MESODON THYROIDUS & & & \\
\hline POMATIOPSIS SCALARIS & & & \\
\hline PUNCTUM MINUTISSIMUM & & & \\
\hline RETINELLA ELECTRINA & & & \\
\hline STROBILOPS LABYRINTHICA & & & \\
\hline SUCCINEA GELIDA & & & \\
\hline SUCCINEA GROSVENORI & & & \\
\hline GRACILICOSTA & & & \\
\hline PARVULA & & & \\
\hline VERTIGO HUBRICHTI & & & \\
\hline ZONITOIDES ARBOREUS & & & \\
\hline GYRAULUS ALTISSIMUS & & & \\
\hline HELISOMA & & & \\
\hline LYMNAEA DALLI & & & \\
\hline LYMNAEA OBRUSSA DECAMPI & & & \\
\hline LYMNAEA PARVA & & & \\
\hline TRIODOPSIS FOSTERI & & & \\
\hline VALVATA TRICARINATA & & & \\
\hline AMNICOLA LEIGHTONI & & & \\
\hline AMNICOLA LUSTRICA & & & \\
\hline GYRAULUS CRISTUS & & & \\
\hline LYMNAEA PALUSTRIS & & & \\
\hline VALVATA SINCERA & & & \\
\hline ALLOGONA PROFUNDA & & & \\
\hline ANGUISPIRA KOCHI & & & \\
\hline TRIODOPSIS HUBRICHTI & & & \\
\hline TRIODOPSIS ALTONENSIS & & & \\
\hline
\end{tabular}

Fig. 3 - Time-stratigraphic distribution of Wisconsinan snall faunas. Gastrocopta procera also should be included in the Woodfordian. 


\section{PLATE 3 \\ MISCELLANEOUS TERRESTRIAL GASTROPODS OF WOODLAND BORDERS AND PRAIRIES}

Various magnifications

Figs. A, B, C. - Euconulus fulvus (Müller); umbilical, apertural, and spiral views, respectively. Peoria loess, NW $\frac{1}{4}$ NE $\frac{1}{4}$ sec. 33, T. 9 N., R. 13 W., Greene County. Enlarged approximately $6 \mathrm{X}$.

Figs. D, E, F. - Belicodiscus parallelus (Say); umbilical, spiral, and apertural views, respectively. Peoria loess, SW $\frac{1}{4}$ NE $\frac{1}{4}$ SW $\frac{1}{4}$ sec. 4, T. 8 N., R. 13 W., Jersey County. Enlarged approximately $6 X$.

Figs. G, H, I. - Retinella electrina(Gould); umbilical, apertural, and spiral views, respectively. Peoria loess, SW $\frac{1}{4} \mathrm{NE} \frac{1}{4} \mathrm{SW} \frac{1}{4}$ sec. 4, T. 8 N., R. 13 W., Jersey County. Enlarged approximately $6 \mathrm{X}$.

Figs. J, K. - Vallonia gracilicostaReinhardt; umbilical and spiral views, respectively. Peoria loess, "The Rocks" section, l mile SE of bridge on Ohio River, Shawneetown, Illinois, in Union County, Kentucky. Enlarged approximately 6X.

Figs. L, M, N. - Hendersonia occultı (Say); umbilical, apertural, and spiral views, respectively. Peoria loess, "The Rocks" section, l mile SE of bridge on Ohio River at Shawneetown, Illinois, in Union County, Kentucky. Enlarged approximately $3 \frac{1}{2} X$.

Figs. O, P. - Discus cronkhitei (Newcomb); umbilical and spiral views, respectively. Peoria loess, "The Rocks" section, l mile SE of bridge on Ohio River at Shawneetown, Illinois, in Union County, Kentucky. Enlarged approximately $3 X$.

Figs. Q, R. - Discus macclintocki Baker; umbilical and spiral views, respectively. Peoria loess, SW $\frac{1}{4}$ NE $\frac{1}{4}$ SW $\frac{1}{4}$ sec. 4, T. 8 N., R. 13 W., Jersey County. Enlarged approximately $22 / 3 X$.

Figs. S, T, U. - Haplotrema concauum (Say); umbilical, apertural, and spiral views, respectively. Peoria loess, NW corner SE $\frac{1}{4} \mathrm{SE} \frac{1}{4} \mathrm{sec} .29, \mathrm{~T} .4$ N., R. 8 W., Madison County. Enlarged approximately $12 / 3 \mathrm{X}$.

Figs. V, W, X. - Stenotrema leai (Binney); umbilical, apertural, and spiral views, respectively. Peoria loess, SE corner SW $\frac{1}{4}$ NW $\frac{1}{4}$ sec. 17, T. 18 N., R. 10 W., Cass County. Enlarged a pproximately 2 2/3X.

Fig. Y. - Cionella lubrica (Müller); a pertural view. Peoria loess, NE corner SW $\frac{1}{4}$ SW $\frac{1}{4}$ sec. 17, T. 18 N., R. 10 W., Cass County. Enlarged approximately $7 \mathrm{X}$.

Figs. AA, BB, CC. - Stenotrema hirsutum (Say); umbilical, apertural, and spiral views, respectively. Roxana silt, Pleasant Grove section, center SE $\frac{1}{4} \mathrm{sec}$. 20, T. 3 N., R. 8 W., Madison County. Enlarged approximately $4 X$.

Fig. Z. - Succinea grosvenori Lea; apertural view. Peoria loess, "The Rocks" section, 1 mile SE of bridge on Ohio River at Shawneetown, Illinois, in Union County, Kentucky. Enlarged approximately $3 \frac{1}{2} \mathrm{X}$.

Fig. DD. - Succinea gelida Baker; apertural view. Peoria loess, SW $\frac{1}{4}$ NE $\frac{1}{4} S W \frac{1}{4}$ sec. 4, T. 8 N., R. 13 W., Jersey County. Enlarged approximately $3 \frac{1}{4} X$.

Figs. EE, FF, GG. - Stenotrema fraternum (Say); umbilical, apertural, and spiral views, respectively. Peoria loess, SW $\frac{1}{4}$ NE $\frac{1}{4}$ SW $\frac{1}{4}$ sec. 4, T. 8 N., R. 13 W., Jersey County. Enlarged approximately $3 \frac{1}{2} \mathrm{X}$. 

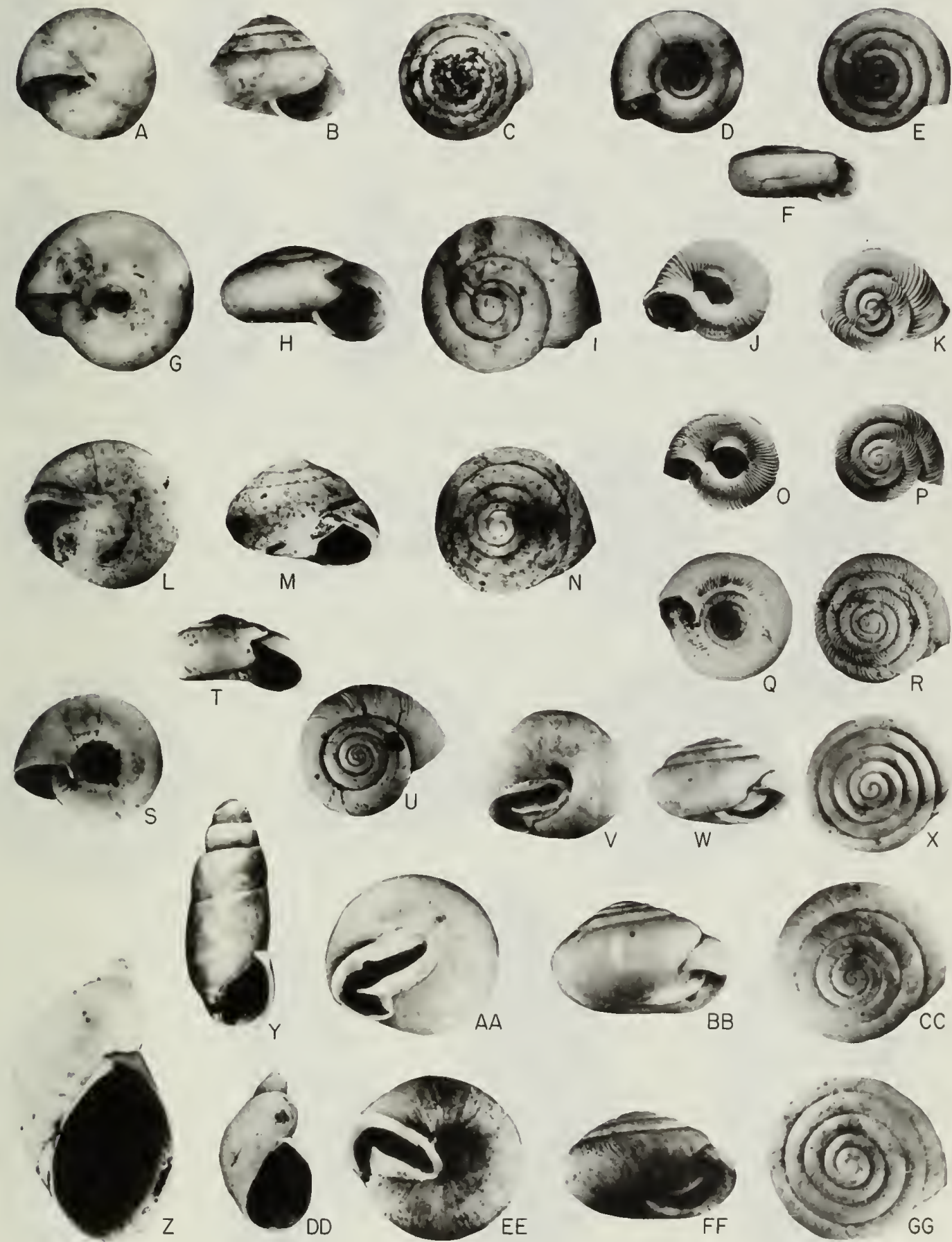

Z 

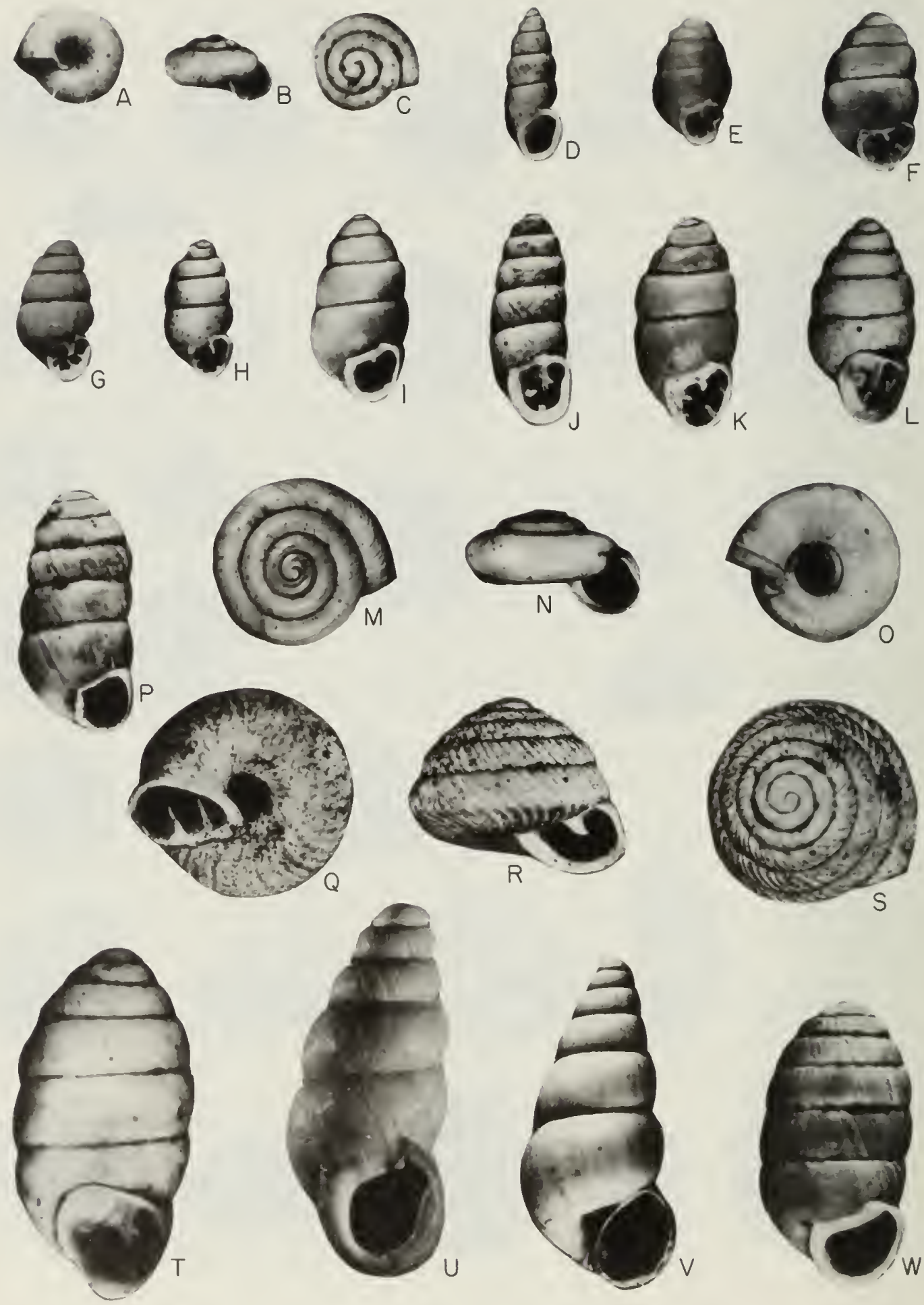


\section{PLATE 4}

\section{PUPILLID AND OTHER MINUTE GASTROPODS}

\section{Most figures enlarged 12 times}

Figs. A, B, C. - Punctum minutissimum (Lea); umbilical, apertural, and spiral views, respectively. Peoria loess, "The Rocks" section, 1 mile SE of bridge on Ohio River at Shawneetown, Illinois, in Union County, Kentucky . Enlarged approximately $12 \mathrm{X}$.

Fig. D. - Carychium exile canndense Clapp; apertural view. Basal zone Peoria loess, SE $\frac{1}{4}$ SW $\frac{1}{4}$ sec. 26, T. 4 N., R. 3 E., Fulton County. Enlarged approximately $12 \mathrm{X}$.

Fig. E. - Vertigo miliumGould; apertural view. Basal zone Peoria loess, SE $\frac{1}{4} S W \frac{1}{4}$ sec. 26, T. 4 N., R. 3 E., Fulton County. Enlarged approximately $12 \mathrm{X}$.

Fig. F. - Vertigo hubrichti Baker; apertural view. Peoria loess, NE corner SW $\frac{1}{4}$ SW $\frac{1}{4}$ sec. 17, T. 18 N., R. 10 W., Cass County. Enlarged approximately 12X.

Fig. G. - Gastrocopta holzingeri (Sterki); a pertural view. Peoria loess, NE corner SW $\frac{1}{4}$ SW $\frac{1}{4}$ sec. 17, T. 18 N., R. 10 W., Cass County. Enlarged approximately $12 \mathrm{X}$.

Fig. H. - Gastrocopta pentodon (Say); apertural view. Peoria loess, SE $\frac{1}{4} \mathrm{SW} \frac{1}{4} \mathrm{sec}$. 26, T. 4 N., R. 3 E., Fulton County. Enlarged approximately $12 \mathrm{X}$.

Fig. I. -Vertiछo alpestris ouछhtoni Pilsbry; apertural view. Morton loess, $S W \frac{1}{4} \mathrm{NE} \frac{1}{4}$ NE $\frac{1}{4}$ sec. 16, T. 30 N., R. 1 W., Marshall County. Enlarged approximately $12 \mathrm{X}$.

Fig. J. - Gastrocopta procera (Gould); apertural view. Peoria loess, NE corner SW $\frac{1}{4}$ SW $\frac{1}{4}$ sec. 17, T. 18 N., R. 10 W., Cass County. Enlarged a pproximately $12 \mathrm{X}$.

Fig. K. - Vertigo modesta (Say); a pertural view. Peoria loess, SE corner SW $\frac{1}{4} N W \frac{1}{4}$ sec. 17, T. 18 N., R. 10 W., Cass County. Enlarged approximately $12 \mathrm{X}$.

Fig. L. - Gastrocopta contracta (Say); apertural view. Peoria loess, SE corner SW $\frac{1}{4}$ NW $\frac{1}{4}$ sec. 17, T. 18 N., R. 10 W., Cass County. Enlarged approximately 12 X.

Figs. M, N, O. - Bawaiia minuscula (Binney); spiral, apertural, and umbilical views, respectively. Peoria loess, SE corner SW $\frac{1}{4}$ NW $\frac{1}{4}$ sec. 17, T. 18 N., R. 10 W., Cass County. Enlarged approximately $12 \mathrm{X}$.

Fig. P. - Columella alticola (Ingersoll); apertural view. Peoria loess, NE corner SW $\frac{1}{4}$ SW $\frac{1}{4}$ sec. 17, T. 18 N., R. 10 W., Cass County. Enlarged approximately $12 X$.

Fig. Q, R, S. - Strobilops labyrinthica(Say); umbilical, apertural, and spiral views, respectively. Roxana silt, Gale section, center sec. 33, T. 14 S., R. 3 W., Alexander County. Enlarged approximately 12X.

Fig. T. - Gastrocopta armifera (Say); apertural view. Woodfordian terrace silts, SW corner NW $\frac{1}{4}$ sec. 23, T. 7 S., R. 4 W., Pike County. Enlarged approximately $10 \mathrm{X}$.

Fig. U. - Pupoides albilabris (Adams); apertural view. Peoria loess, Irish Grove section, center NE $\frac{1}{4}$ sec. 25, T. 19 N., R. 5 W., Menard County. Enlarged approximately $12 \mathrm{X}$.

Fig. V. - Pomatiopsis scalaris Baker; apertural view. Peoria loess, Enion section, SE corner NW $\frac{1}{4} \sec .33$, T. 4 N., R. 3 E., Fulton County. Enlarged approximately $7 \frac{1}{2} \mathrm{X}$.

Fig. W. - Pupilla muscorum (Linné); apertural view. Peoria loess, Banner section, NW $\frac{1}{4}$ NE $\frac{1}{4}$ sec. 10, T. 6 N., R. 5 E., Fulton County. Enlarged approximately $12 \mathrm{X}$. 
Total numbers of molluscan species in any single Peoria fauna range from as many as 26 (locality 57 a) to as few as three (locality 25); a typical assemblage comprises approximately 12 species.

The Peoria fauna is distinctive and readily recognizable, even in the field. The predominant species are small mollusks; the only relatively large shells that occur are Anguispira alternata, Triodopsis algonquinensis, and occasionally T. multilinenta. The last two, as far as present information goes, are restricted to the Woodfordian. Succinea selida, Stenotrema hirsutum, S. leai, Bendersonia occulta, and either Discus cronkhite $i$ or $D$. macclintocki, although of only moderate size, frequently are conspicuous in a local fauna. Among the minute species Columella alticola, Euconulus fulvus, and Vertigo modesta are most commonly recovered in the Peoria loess.

The Peoria fauna shows significant variation from north to south in the Illinois Valley region. Among the species of reasonably frequent occurrence, Carychium exile canadense, Columella alticola, Discus cronkhitei, and Pupilla muscorum are either restricted to the northernmost part of the region, or reach their greatest population density there, while Discus macclintocki, Hawaiia minuscula, Baplotrema concavum, Vertigo hubrichti, and Anguispira alternata occur most frequently in the southern localities.

\section{Ecological Considerations}

A complete picture of the paleoecological conditions prevailing in Illinois during the time of deposition of the Peoria loess cannot be fully reconstructed. The thick, highly fossiliferous loess exposures are near the major valleys, and the loess thins rapidly away from them. Because relief is relatively less pronounced away from the valleys, suitable exposures are less frequent and those available generally are so deeply leached that all snail shells have been destroyed. It is obvious from the species composition of Peoria assemblages that the great deciduous forests of Altonian time (at least as they appeared in the southern half of Illinois) did not occur in Woodfordian in northern Illinois. This is not to say that the vegetative cover was reduced to a prairie situation; the presence of Anguispira alternata, Mesodon clausus, and the several species of Stenotrema in the Peoria loess attests to the presence of stands of trees. The general vegetational cover must have consisted of stands of trees along stream courses, and perhaps elsewhere, interspersed with large areas of open prairie. Correspondingly, the climate was likely less stable and perhaps less humid than that existing in Altonian (and perhaps Farmdalian) time, although the occurrence of Corychium exile canadense, Lymnaea parva, Pomatiopsis scalaris, Triodopsts algonquinensis, and $T$. multilineata clearly show that the climate could not have been deficient in rainfall. Carychtum exile canndense, Euconulus fulvus, Pupilla muscorum, andVertigo alpestris oughtoni support the thesis that the Woodfordian climate was somewhat cooler than today, even in northern Illinois, for these species are today characteristic of molluscan faunas in the Canadian Life Zone.

\section{Faunal Assemblages from Morton Loess}

The post-Farmdale - pre-Shelbyville Morton loess (formerly classified as the Iowan loess) in our studies is represented by two fossiliferous localities (10 and 23, fig. 2). From these a total of 12 species is known: Columella alticola, Discus cronkhitei, Haplotrema concaum, Hendersonia occulta, Lymnaea dalli, 
Pupilla muscorum, Retinella electrina, Stenotrema leai, Succinea gelida, Triodopsis algonquinensis, Vertigo alpestris oughtoni, and $V$. modestr. This assemblage is not unlike those typical of northern localities of the Peoria loess. It lacks Discus macclintocki, which does not occur anywhere inside the Shelbyville morainal front. Columella alticola, Hendersonia occulta, and Pupilla muscorum are abundant, and along with Succinea gelida are the most conspicuous faunal elements of the Morton loess. From the scant evidence available, it is not now possible to distinguish the fauna of the Morton loess from that of Peoria loess in northern Illinois.

Faunal Assemblages from Richland Loess

The Richland loess, situated stratigraphically above the earliest Woodfordian moraines, is represented at localities 2, 14, and 22 (fig. 2). The combined assemblage from these collecting stations totals 12 species: Columella alticoln, Discus cronkhitei, Euconulus fulvus, Gyraulus altissimus, Lymnaea dalli, L. obrussa decampi, Pisidium compressum, P. caseratanum, Pupilla muscorum, Succinea gelida, Vallonia gracilicosta, and Vertigo modesta.

The character of the assemblage is not significantly different from that of those found in the Morton loess or in the Peoria loess of northern Illinois. At locality 22 the loess evidently accumulated on a poorly drained surface, as attested by the presence of three genera (Gyraulus, Lymnaea, and Pisidium) of aquatic mollusks. We believe this reflects nothing more than an anomalous local ecological condition.

Faunal Assemblages from Normal and Metamora Moraines

At two localities fossil shells were obtained from silt inclusions in glacial till, one in the Normal ground moraine (locality 9) and one in the Metamora ground moraine (locality 13). From the first deposit only a meager series was obtained: Discus cronkhitei, Helicodiscus parallelus, and Succinea grosvenori. The second collecting station yielded eight species, including Columella alticola, Discus cronkhitei, Euconulus fulvus, Pupilla muscorum, Succinea gelida, Vallonia gracilicosta, Vertigo hubrichti, and $V$. modesta.

The first of these collections obviously has little significance aside from its unusual occurrence within a till mass; the second closely resembles that from the Morton and Richland loess, or, for that matter, the Peoria loess of northern Illinois.

The ecological significance of these molluscan assemblages from silt-intill inclusions is considerable, especially as the shells at locality 13 are abundant and had suffered no discernible damage before our collections were made. Several hundred shells were obtained from a bulk sample of approximately 100 pounds of silt. Inasmuch as the fauna is similar to that found in loesses of the region, including those outside the Wisconsinan glacial boundary, it is evident that continental glaciation at the latitude of northern Illinois did not have a profound effect upon local climate at any considerable distance from the ice front. As the nearly perfect state of preservation of the shells argues against long transportation from other deposits, we can safely assume that the gastropods found in the silts lived at one time within a stone's throw of the glacial front. Although well preserved shells were collected from sand and silt streaks in till in northeastern Kansas (Frye and Leonard, 1952), to our knowledge the Illinois localities are the most northerly yet reported to yield from a till mass shells in sufficient numbers to make it evident that the animals were living near the ice front. 


\section{Faunal Assemblages from Woodfordian Terrace Deposits}

The emphasis in this report is on faunal assemblages from loess deposits, but during our field work we made six collections (fig. 2) from deposits that may be referred to as Woodfordian terraces. The snails from locality 2 were collected from terrace sand and silt; those from locality 6 were recovered from a 6 -inch zone of coarse gray silt below Bloomington till; those from locality 7 occurred in sand and silt in deltaic deposits in front of the Arlington (Cropsey) moraine; shells at locality 35 were collected from a silty band in a 15-foot roadcut exposure of sand and silt below loess. Only the assemblages from localities 41 and 42 came from typical terrace deposits. An organized study of molluscan faunal assemblages in Pleistocene terraces in Illinois remains to be made.

The total assemblage from these six collecting stations ranges from six species (localities 6, 7) to 11 species (locality 35 ). Except for the occurrence of Valvata tricarinata at locality 41 , each of the local faunas has little to distinguish it from Woodfordian assemblages from loess in the near vicinity. In view of the paucity of data from the terraces, no generalities concerning them can, or should, be made at this time.

\section{SUMMARY}

The recent revision of the classification of the Wisconsinan Stage of the Pleistocene in Illinois (Frye and Willman, 1960) has made possible a systematic evaluation of late Pleistocene molluscan faunas within a firmly established stratigraphic framework. Although Pleistocene mollusks have been known for many years (Baker, 1920), this paper presents for the first time the results of an organized study of fossil mollusks within a discrete segment of Pleistocene time over a significant geographical region of Illinois.

The molluscan faunal assemblages treated here are grouped under the Altonian, Farmdalian, and Woodfordian Substages of the Wisconsinan Stage; fossiliferous sediments of Twocreekan and Valderan Substages have not yet been recognized in the Illinois Valley region.

The Altonian Substage is represented by the Roxana silt from the approximate latitude of the mouth of the Sangamon River to Alexander County. The Roxana silt, although not fossiliferous throughout, yields a molluscan fauna of distinctive qualities, characteristic of those found in climactic deciduous forests. Only two species, Priodopsis altonensis and T. hubrichti, seem to be definitely restricted to Altonian faunas, but the typical assemblage embraces also Allogona profundn (which occurs outside the Altonian at only one Farmdalian locality), Anguispira alternatn, and occasionally A. kochi, Hendersonia occulta, Stenotrema fraternum, Stenotrema hirsutum, Succinea ovalis, and other less frequently occuring species. A total of 28 species are known from the Roxana silt at 11 localities.

Collections from three exposures of Farmdale silts yielded a total of 24 species, but because of the widely separated geographic distribution of the localities and the unusual qualities of each, the Farmdalian faunal assemblage is not yet well characterized. In the water-laid deposits in LaSalle and McLean Counties the predominant species areValvata tricarinata, $V$. sincera, Amnicola leightoni, A. lustrica, and shells of several species of Pisidium. Predominant species in the single southern locality, at the latitude of Gallatin County, are Anछuispira alternatn, A. kochi, Allogona profunda, and Succinea ovalis. This southern fauna, like that from the Altonian of the same region, is characteristic of deep forests. 
Molluscan faunas were recovered from loess, moraines, outwash, inclusions of sand and silt within till, and from terrace deposits of Woodfordian age. Collecting stations include 37 localities in the Peoria loess, two in the Morton loess, and three in the Richland loess; two collections were made from silt-in-till inclusions in the Normal and Metamora moraines, and six from Woodfordian terrace silts.

The total Woodfordian faunal assemblage comprises 55 species, of which 22 species were not found at other stratigraphic levels. Predominant species in the well defined assemblage include Columella alticola, Euconulus fulvus, Stenotrema leai, Triodopsis algonquinensis, and Vertigo modesta, all seemingly restricted to the Woodfordian, and Anछuispira alternata, Hendersonia occulta, Stenotrema hirsutum, Succinea ovalis, S. gelida, S. grosvenori, Discus cronkhitei, and D. macclintocki, each of which also occurs in other Wisconsinan assemblages.

Woodfordian faunas display distinctive geographical differences from north to south, but on the basis of present evidence it is not possible to make stratigraphic distinctions within the substage.

Interpretations of paleoecology may be generalized as follows: At least in the region south of Sangamon River, Illinois was heavily forested in Altonian time; these dense forests, existing in a climate more humid than the present one, continued through Farmdalian time and perhaps, in southern Illinois, into earliest Woodfordian. After Farmdalian time the vegetative cover was of a much more open type, perhaps essentially a mixed prairie, with trees and shrubs restricted to borders of stream courses and other favorable situations.

There is no evidence of extremely rigid climates during Woodfordian time, even in areas adjacent to ice fronts, although northern Illinois is judged to have had a climate approximating that of the present Canadian Life Zone.

\section{REFERENCES}

Baker, F. C., 1920, The life of the Pleistocene or glacial period: Univ. Illinois Bull. 17.

Frye, J. C., and Leonard, A. B., 1952, Pleistocene geology of Kansas: Kansas Geol. Survey Bull. 99, 230 p.

Frye, J. C., and Willman, H. B., 1960, Classification of the Wisconsinan Stage in the Lake Michigan glacial labe: Illinois Geol. Survey Circ. 285, 16 p.

Goodrich, Calvin, 1932, The Mollusca of Michigan: Univ. Michigan Michigan handbook ser. mus. zool. no. 5, p. 1 - 120, figs. 1 - 7 .

de Heinzelin, J., 1959, Problemes du Pleistocene dans le Middle West (U. S. A.): Soc. belge géologie Bull., tome LXVII, p. 265 - 290.

Leighton, M. M., 1948, Footnote on p. 390, in Washer, H. L., et al., Loess in the southern Mississippi Valley - Identification and distribution of loess sheets: Soil Sci. Soc. Amer. Proc. 1947, v. 12, p. 389 - 399.

Smith, G. D., 1942, Illinois loess - variations in its properties and distribution: a paleologic interpretation: Univ. Illinois Agr. Exp. Sta. Bull. 490, p. $139-184$.

Wayne, W. J., 1959, Stratigraphic distribution of Pleistocene land snails: Sterkiana, no. 1, p. $9-18$. 


\author{
GEOLOGIC SECIION S
}

The locations of the 11 measured geologic sections presented here and of four similar sections published in Circular 285 are shown on the map in figure 1. The numbers enclosed in parentheses, for example (P-762), refer to samples collected for mineralogical study and will be described in a subsequent report. The sections are arranged alphabetically by name.

\title{
ALTON QUARRY SECTION
}

SE $\frac{1}{4} \operatorname{SW} \frac{1}{4}$ NE $\frac{1}{4}$ sec. 10, T. 5 N., R. 10 W., Madison County, Illinois; measured in Mississippi Lime Company quarry, 1958. (Type locality of Altonian Substage). Measured by John C. Frye and H. B. Willman

Pleistocene Series

Wisconsinan Stage

Thickness

Woodfordian Substage

Peoria loess

9. Loess, coarse, massive, yellow-tan, weakly calcareous $(\mathrm{P}-20)$.

Altonian Substage

Roxana silt

8. Loess, coarse, massive, pinkish $\tan (\mathrm{P}-21)$, gradational with yellow-tan above; weakly calcareous; fossil snails sparse (locality 54 ).

7. Loess, massive, noncalcareous, nonfossiliferous, medium (feet) gray to gray-tan ( $\mathrm{p}-22)$; sharply truncated at top and a darker zone gradational at base.

Illinoian Stage

6. Silt, sand, and clay, massive, noncalcareous, reddish brown, general appearance of colluvium $(\mathrm{P}-23)$. This zone is entirely within the A- and B-horizons of a soil profile 7 feet thick that extends into the underlying unit.

5. Till, massive, highly calcareous except the uppermost 5 feet which is leached (p-24, 2 feet below top), relatively fine-textured, blue-gray to dark gray (P-26, 10 feet below top). A one-foot sand zone (P-25) occurs 8 feet below the top; lowermost 10 feet contains distorted masses and bands of gray silt, fragments of wood, and scattered snail shells.

4. Silt, massive, light gray at bottom grading upward to dark gray, calcareous, fossiliferous, gradational at base, stems and wood fragments in upper part, and at top a thin clay slickenside zone suggesting glacial override.

3. Silt, loess or loess-like, massive, calcareous, yellowbuff, limonite banding in upper part ( $\mathrm{P}-27)$; contains abundant fossil snails.

2. Silt, loess or loess-like, massive, weakly calcareous, tan to yellowish buff, limonitic banding.

1. Silt, very fine sand, and clay, thinly laminated, noncalcareous, rusty brown to chocolate (P-28); rests on Mississippian St. Louis Limestone at a low point on the unconformable surface. 
BANNER SECTION

NW $\frac{1}{4}$ NE $\frac{1}{4}$ sec. 10, T. 6 N., R. 5 E., Fulton County, Illinois Measured in new cuts along Highway 9, 1958

Pleistocene Series

Wisconsinan Stage

Woodfordian Substage

Peoria loess

4. Loess, massive with local platyness, medium, yellow-tangray, calcareous ( $\mathrm{P}-118$ ); upper 8 feet leached in surface soil; contains fossil snails (locality 15).

Thickness

(feet)

Farmdalian Substage

Farmale silt

3. Silt, massive to platy, purple-brown to purple-gray, noncalcareous; charcoal flakes in upper part (P-117 upper; P-116 lower).

2. Sand, silt, and a few pebbles, massive, yellow-tan at bottom grading upward to gray-brown; locally weakly

Illinoian Stage calcareous; colluvium (P-115).

1. Till, compact, pebbly, gray and $\tan$, calcareous (P-113); contains included blocks of gray silt with a few fragmentary snail shells; upper 2 feet leached (P-114), appears to be truncated soil.

Total Pleistocene

\section{BLUFFDALE SECTION}

NW $W_{4}^{\frac{1}{4}}$ NW $\frac{1}{4}$ sec. 3, T. 10 N., R. 13 W., Greene County, Illinois, 1958, overburden of abandoned quarry

Pleistocene Series

Wisconsinan Stage

Woodfordian Substage

Peoria loess

4. Loess, massive to indistinctly bedded, gray-tan, weakly calcareous, sparsely fossiliferous; gradational at base; basal contact and indistinct bedding dip away from valley.

Substage

Altonian Substac
Roxana silt

3. Loess, massive, pink, weakly calcareous to noncalcareous; basal contact forms arch in truncated spur; contains several pods of Celtis occidentalis seeds and fossil snails (locality 46).

2. Silt, massive, gray and gray-tan mottled, scattered angular chert fragments.

1. Rubble of angular chert fragments with random orientation in a clay matrix, covered at the base.

Total Pleistocene measured

\section{BROWNS MOUND SECTION}

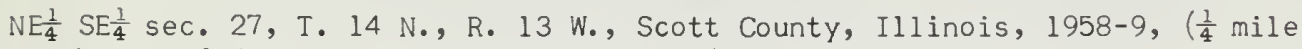
southwest of deep cuts along Hwy. U. S. 36, studied and collected in 1953 and 1955). Section as exposed in August 1958 and May 1959.

Measured by John C. Frye, A. Byron Leonard, and H. B. Willman 
Pleistocene Series

Wisconsinan Stage

Woodfordian Substage

Peoria loess

9. Loess, with lenticular inclusions of sand; loess massive, gray to yellow-tan, coarse, calcareous except in soil profile at top, fossiliferous; sand medium to fine and coarse, cross-bedded, light tan to gray, locally mottled with soft limonite, sand lentils occur throughout and locally truncate bed below. Fossil snails were collected both here and from the upper and presumed equivalent unit in the nearby roadcut (locality 43). (P-282, P-283 loess; P-286 cross-bedded sand.) Maximum thickness.

ilt and fine to medium sand, thin-bedded, horizontal, graytan, gray and yellow-tan, contains sparse Succinea cf. grosuenori; occurs only as lenticular body on east side of quarry, basal contact truncates pink loess below and top is truncated by the cross-bedded sands of unit 8 (P-285).

Altonian Substage

Roxana silt

7. Loess, medium to coarse, massive, pink to pinkish tan, weakly calcareous to noncalcareous, lenticular bodies of sand (P-280) occur at west side of quarry, gradational at top with overlying loess where lenticular bodies of sand and interbedded sand and silt are not present (P-281 from pink loess above sand body). [Re-examination of the quarry in September 1959 and May 1960, after the overburden face was significantly farther back from the buff-line and past the limit of the sand lentils, showed bed 9 resting on pink loess, above gray-tan loess that rested directly and conformably on bed 7 . The top of the Roxana is at the top of the upper pink loess.] (Fauna locality 45).

6. Silt, gray, massive, noncalcareous, gradational at top but resting with sharp contact on top of soil below. (The face as exposed in May 1960 showed this unit thicker and with 2 feet of sand locally at base.)

Pre-Wisconsinan Stages

5. Silt, sandy, massive, gray, noncalcareous except locally at base where it is weakly calcareous, in east side of quarry has soil at top with well developed red-brown B-horizon and some structure and manganese staining; westward across quarry face, soil is truncated, and at west end the overlying loess rests directly on the leached till below. Locally contains a sparse snail fauna. ( $\mathrm{P}-278$ gray loess; P-279 B-horizon of soil.)

4. Till, massive, compact, blue-gray, calcareous in lower part; at west side of quarry a truncated soil was observed in 1958 in upper part of till; in middle part of quarry till pinched out over bedrock high (P-277).

3. Silt, massive, tan, noncalcareous, occurs in local lenses between till and underlying sand (P-276).

2. Sand, with a few pebbles, massive to bedded, gray to tan,

noncalcareous, loose; lenticular, ranges from a few inches to 6 feet in thickness (P-275). inches to 6 feet in thickness (P-275). 
Thickness

(feet)

1. Silt, indistinctly bedded to massive, compact, red-tan to gray-tan, with a few streaks of sand; maximum thickness in west side of quarry, pinching out to the east $(\mathrm{P}-274)$.

Pleistocene deposits rest on Mississippian limestone.

Maximum total thickness

\section{COTTONWOOD SCHOOL SECTION}

Center E. line, sec. 11, T. 18 N., R. 11 W., Cass County, Illinois Measured along road cuts, 1958, 1959, by John C. Frye, A. Byron Leonard, and H. B. Willman.

Pleistocene Series

Wisconsinan Stage

Woodfordian Substage

Peoria loess

9. Loess, coarse, gray-tan to pale yellow, massive to indistinctly thin-bedded and laminated, sparsely fossiliferous, calcareous ( $\mathrm{P}-110)$.

8. Loess, coarse to medium, massive, gray-tan, a fine-
textured zone gradational at top (P-109), indistinct
streaks of pale pink throughout, calcareous (P-107
and P-108); contains fossil snails (locality 32).
tonian Substage

8. Loess, coarse to medium, massive, gray-tan, a fine-
textured zone gradational at top (P-109), indistinct
streaks of pale pink throughout, calcareous (P-107
and P-108); contains fossil snails (locality 32).
tonian Substage

8. Loess, coarse to medium, massive, gray-tan, a fine-
textured zone gradational at top (P-109), indistin
streaks of pale pink throughout, calcareous (P-107
and P-108); contains fossil snails (locality 32).
tonian Substage

8. Loess, coarse to medium, massive, gray-tan, a fine-
textured zone gradational at top (P-109), indistinct
streaks of pale pink throughout, calcareous (P-107
and P-108); contains fossil snails (locality 32 ).
Altonian Substage

8. Loess, coarse to medium, massive, gray-tan, a fine-
textured zone gradational at top ( $\mathrm{P}-109)$, indistinct
streaks of pale pink throughout, calcareous (P-107
and P-108); contains fossil snails (locality 32).
tonian Substage

Roxana silt

7. Loess, coarse, massive, dark pink in lower part (P-104) grading upward $(\mathrm{P}-105)$ to pinkish gray in upper part (P-106); noncalcareous to weakly calcareous, very sparsely fossiliferous throughout.

6. Loess, medium, massive, neutral gray, limonite tubules, weakly calcareous; sharp contact at top (P-102, lower; P-103 upper).

5. Loess, medium, massive, pinkish-tan, gradational upward with gray loess and sharp contact at base; limonite tubules and small calcium carbonate concretions throughout, weakly calcareous but nonfossiliferous (P-100, lower; P-10l upper).

Illinoian Stage
4. Silt, massive, light gray to medium gray with some mottling
with tan, noncalcareous; small angular fragments of chert
and small pebbles sparsely throughout; colluvium (P-99).
4. Silt, massive, light gray to medium gray with some mottling
with tan, noncalcareous; small angular fragments of chert
and small pebbles sparsely throughout; colluvium (P-99).
4. Silt, massive, light gray to medium gray with some mottlin
with tan, noncalcareous; small angular fragments of cher
and small pebbles sparsely throughout; colluvium (P-99).

3. Till, compact, pebbly and cobbly; in lower half gray, calcareous, tough ( $P-97)$; upper half in soil profile, leached, red-brown, sandy, clayey, friable (P-98).

2. Silt, compact, blocky, calcareous, banded gray and $t a n$, contains some sand and pebbles (P-96).

1. Till, compact, massive, pebbly, calcareous, gray to graybrown (P-95); rests on Pennsylvanian shale and siltstone. 
FREDERICK SOUTH SECTION

SE $\frac{1}{4} N E_{\frac{1}{4}}^{\frac{1}{4}} E_{\frac{1}{4}}^{-1} \mathrm{sec} .18, T .1$ N., R. 1 E., Schuyler County, Illinois. in borrow pit, 1959 .

Measured by John C. Frye, A. Byron Leonard, and H. B. Willman.

Pleistocene Series

Wisconsinan Stage

Thickness

(feet)

Woodfordian Substage

Peoria loess

12. Loess, tan to yellow-tan, massive, strongly calcareous below a 4-foot surface soil (P-599 calcareous loess; P-600 B-horizon of surface soil). Yielded fossil snails (locality 29).

11. Loess (weakly developed soil profile), medium tan-brown with carbonaceous flecks and small spots of secondary calcium carbonate, matrix weakly calcareous, nonfossiliferous (P-598).

10. Loess, gray-tan, massive, coarse, strongly calcareous (P-596 2 feet above base; P-597 9 feet above base).

Altonian Substage

Roxana silt

9. Silt, coarse, pink with transition to tan in upper 2 feet, weakly calcareous becoming strongly so in transition zone at top, fossiliferous (P-594 middle; P-595 top).

8. Silt, coarse, and very fine sand, sandier in base, tan in

base becoming light tan-brown in top, massive, weakly
calcareous, sparse snail fauna (P-592 lower; P-593 upper)
7. Sand, fine to very fine, grading upward to silt, medium-tan
in base grading upward to light tan-brown, weakly
calcareous; sparse snail fauna (P-590 base; P-59l upper).

base becoming light tan-brown in top, massive, weakly
calcareous, sparse snail fauna (P-592 lower; P-593 upper).
7. Sand, fine to very fine, grading upward to silt, medium-tan
in base grading upward to light tan-brown, weakly
calcareous; sparse snail fauna (P-590 base; P-59l upper).

base becoming light tan-brown in top, massive, weakly
calcareous, sparse snail fauna (P-592 lower; P-593 upper)
7. Sand, fine to very fine, grading upward to silt, medium-tan
in base grading upward to light tan-brown, weakly
calcareous; sparse snail fauna ( $\mathrm{P}-590$ base; P-59l upper).
6. Silt, coarse, and very fine sand, pink, massive, compact,

base becoming light tan-brown in top, massive, weakly
calcareous, sparse snail fauna (P-592 lower; P-593 upper)
7. Sand, fine to very fine, grading upward to silt, medium-tan
in base grading upward to light tan-brown, weakly
calcareous; sparse snail fauna (P-590 base; P-59l upper).

base becoming light tan-brown in top, massive, weakly
calcareous, sparse snail fauna (P-592 lower; P-593 upper)
7. Sand, fine to very fine, grading upward to silt, medium-tan
in base grading upward to light tan-brown, weakly
calcareous; sparse snail fauna (P-590 base; P-59l upper).
6. Silt, coarse, and very fine sand, pink, massive, compact, calcareous ( $\mathrm{P}-589$ ); contains fossil snails (locality 29).

5. Sand, fine, and coarse silt, medium gray-tan, calcareous, massive, gradational top and bottom, nonfossiliferous (P-588).

4. Colluvium of silt with some sand, scattered coarse sand grains and pebbles, tan to tan-brown, noncalcareous (P-587).

Pre-Wisconsinan Stages

3. Soil, with 3-foot profile, red-brown B-horizon (P-586),
developed in silty sand, tan, noncalcareous, grading
downward through tan, noncalcareous sand and silty
sand ( $\mathrm{P}-584$ lower; $\mathrm{P}-585$ upper), to 2 feet of calcareous
tan sand in base (P-583).
developed in silty sand, tan, noncalcareous, grading
downward through tan, noncalcareous sand and silty
sand ( $\mathrm{P}-584$ lower; $\mathrm{P}-585$ upper), to 2 feet of calcareous
tan sand in base (P-583).
developed in silty sand, tan, noncalcareous, grading
downward through tan, noncalcareous sand and silty
sand ( $\mathrm{P}-584$ lower; $\mathrm{P}-585$ upper), to 2 feet of calcareous
tan sand in base ( $\mathrm{P}-583)$.
developed in silty sand, tan, noncalcareous, grading
downward through tan, noncalcareous sand and silty
sand ( $\mathrm{P}-584$ lower; $\mathrm{P}-585$ upper), to 2 feet of calcareous
tan sand in base (P-583).

2. Covered in lower part; coarse colluvium composed of sand, silt, blocks of tan sandstone, metamorphic and igneous rock pebbles; strongly calcareous and cemented in discontinuous zones.

ill, gray, calcareous, sandy and pebbly, abundant nodules of $\mathrm{CaCO}_{3}$ in lower 3 feet (P-581), strongly oxidized in upper one foot (P-582); rests on Pennsylvanian sandstone, 


\section{LAKE BLCOMINGTON SPILLWAY SECTION}

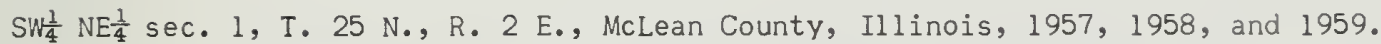
Adapted from earlier section by George E. Ekblaw

Pleistocene Series

Wisconsinan Stage

Thickness

Woodfordian Substage

Richland loess

10. Loess, oxidized, leached, massive, buff .

Normal till

9. Till, clayey, massive, gray-tan, leached in uppermost part $(P-148)$.

8. Sand and gravel, calcareous, $\tan (P-147)$.

2.0

Normal or Bloomington till

7. Till, massive, pebbly, calcareous, pink-tan (P-146). 3.0

Interstadial silt

6. Silt with some sand, massive, weakly calcareous, streaked gray-tan and brown.

Bloomington, Leroy, or Shelbyville till

5. Till, massive, pebbly, calcareous, gray to blue-gray (P-145). 8.0

Farmalian or Altonian Substage

4. Silt, massive, compact, greenish gray to pink-gray with some color banding ( $\mathrm{P}-144)$; contains peaty zones and streaks; lenticular; yielded $C^{14}$ date (W-67) greater than 34,000 years (note conflicting date from bed 1 ). Yielded fossil snails (locality 24 ).

Altonian Substage, or older

3. Till, cobbly and gravelly, relatively loose locally in lower part, in upper part more compact, calcareous, oxidized at top ( $\mathrm{p}-143)$.

2. Till, compact, massive, pebbly, calcareous, gray (P-142).

1. Till, compact, massive, jointed, calcareous, pebbly, purplish-gray, upper 8 inches slightly less calcareous than remainder of till (P-141); top marked by a pavement of pebbles, cobbles, and boulders, all faceted, polished, and striated along a planeate surface. Sample of wood from till gave a $C^{14}$ date of 31,000 or older (w-186); to level of water in spillway channel.

Total Pleistocene measured

\section{MASON COUNTY SECTION}

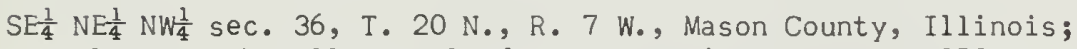
along north valley wall of Sangamon River Valley, 1959.

Measured by John C. Frye, A. Byron Leonard, and H. B. Willman

Pleistocene Series

Wisconsinan Stage

Wood fordian Substage

Thickness

(feet)

Peoria Loess

5. Loess, gray and yellow-tan in indistinct zones, massive, calcareous, medium coarse ( $\mathrm{P}-577$ base); fossil snails

Altonian Substage in upper one-third below the soil profile (locality 28). 40.0

Roxana silt

4. Loess, pink, massive, weakly calcareous, compact, nonfossiliferous (P-576). 
Thickness

(feet)

3. Loess, gray-tan, massive, calcareous, nonfossiliferous, gradational contacts $(\mathrm{P}-575)$.

2. Silt, contains pebbles in lower part becoming sparse upward (colluvium), pink (P-574).

Pre-Wisconsinan Stages

1. Sand and gravel with well developed soil B-horizon, redbrown, clayey, at top truncated by colluvial contact; grades downward into calcareous sand, gravel, and silt, well bedded to poorly bedded (outwash), partly covered in lower part to level of road.

Total

"THE ROCKS" SECTION, KENTUCKY

One mile southeast of bridge across Ohio River at Shawneetown, Illinois. Measured July 1959 by John C. Frye, A. Bryon Leonard, and H. B. Willman.

Pleistocene Series

Wisconsinan Stage

Thickness (feet)

Woodfordian Substage

Peoria loess

5. Loess, gray, massive, calcareous below the surface soil; fossil snails from lower two-thirds of this zone (locality 57A). (P-480 lower.)

20.0

Farmdalian Substage (latest transitional)

4. Loess, gray, massive, coarse, contains $\mathrm{CaCO}_{3}$ nodules; fossil snails (locality 57B). (P-479). Radiocarbon date on snail shells $22,200450(W-867)$.

Altonian Substage

Roxana silt

3. Loess, dark gray to light brown, pink in basal part, massive, noncalcareous to weakly calcareous, nonfossiliferous. This and underlying beds are truncated at a low angle by erosional unconformity at top so that bed 4 rests on bed 1 at side of cut (P-478, top; P-477, middle; P-476, base.)

Illinoian Stage

2. Sangamon soil; red to red-brown clay and silt, scattered $\mathrm{Mn}-\mathrm{Fe}$ pellets, clay skins, gradational at base. (P-475, upper.)

1. Silt, massive, mottled yellow, $\tan$ and red-brown in upper part grading downward to yellow-tan, noncalcareous, nonfossiliferous; rests on Pennsylvanian sandstone (P-474, upper.)

Total Pleistocene

\section{SAVANNA SECTION}

Adjacent to Highway 80 , southwest cor. NW $\frac{1}{4}$ sec. 11, T. 24 N., R. 3 E., Carroll County, Illinois (July 1959).

Measured by John C. Frye, A. Byron Leonard, and H. B. Willman 
Pleistocene Series

Wisconsinan Stage

Woodfordian Substage

Peoria loess

8. Loess, leached, tan, well developed soil profile in

upper part.
7. Loess, calcareous, gray, grading upward into yellow-tan,

Thickness

(f eet) massive; lower 5 feet contains abundant snail fauna (locality 3). (P-526, lower; P-527, upper).

Altonian Substage, or older

6. Sand, very fine, and coarse silt, pale chocolate-brown to medium gray-pink, noncalcareous, massive; gradational at base with A-horizon below and erosional unconformity at top (P-525).

5. Silt, massive, dark gray-brown, grading upward into dark gray A-horizon of A-C soil profile at top (P-523 lower; P-524 upper).

Pre-Wisconsinan Stages

4. Soil, A-horizon; silt with some clay, dark gray-brown, crumb-structure, gradational at base ( $\mathrm{p}-522)$.

3. Soil, B-horizon; silt and clay, red-brown, tough, columnar structure, gradational ( $\mathrm{P}-521)$.

2. Silt, massive, noncalcareous, locally some fine sand, yellow-tan; locally a few scattered pebbles of chert $(\mathrm{P}-520)$.

1. Sand and silt, irregularly bedded, tan to brown, noncalcareous (P-519); rests on weathered Maquoketa Shale.

Total Pleistocene

WEDRON SECTION

Southwest end of quarry of Wedron Silica Company, as exposed on July 27, 1959, in vertical face; SE $\frac{1}{4}$ SE $\frac{1}{4}$ SW $\frac{1}{4}$ sec. 9, T. 34 N., R. 4 E., La Salle County, Illinois. Measured by John C. Frye, A. Byron Leonard, and H. B. Willman

Pleistocene Series

Wisconsinan Stage

Thickness (feet)

Woodfordian Substage

Richland loess, Farm Ridge till, etc.

7. Loess, till, and gravel, weathered and partly obscured by spoil pile.

Cropsey till

6. Till, oxidized, tan, poorly exposed.

Bloomington till

5. Till, pink, bouldery, massive, calcareous, tough; indistinct boulder pavement in middle part.

Shelbyville till

4. Till, gray and tan, calcareous, bouldery, compact, sharp contact at top with an indistinct boulder pavement in top.

Pro-Shelbyville outwash

3. Sand and gravel, loose, tan, calcareous, locally crossbedded and generally well bedded, irregular erosional contact at base. 


\section{Farmdalian Substage}

Farmale silt

2. Silt, clayey, pink to red and red-brown, calcareous, massive to indistinctly bedded but locally thin-bedded and blocky, no fossils observed; locally contains small lenses of fine sand, tan, calcareous; upper contact irregular but lower contact conformable on unit below. From the upper part of this unit in a former working face, wood yielded a $C^{14}$ date of $24,000 \pm 700(W-79) \cdot 10.0$ to 20.0

1. Silt with some clay and fine sand and locally sandy streaks near the top, gray-blue to dark gray or black with some tan zones, massive, compact, calcareous; contains fauna of aquatic mollusks (locality 8 ); humus staining distributed throughout, numerous twigs and wood fragments in upper one-third yielded a $\mathrm{C}^{14}$ date of $26,800 \pm 700(W-871)$; rests on St. Peter Sandstone. 25.0

Total Pleistocene measured

Thickness

(feet)

Illinois State Geological Survey Circular 304 32 p., 3 figs., 4 plates, 11 geol. sections, 1960 



\section{Land of Lincoln?}

CIRCULAR 304

ILLINOIS STATE GEOLOGICAL SURVEY URBANA 